\title{
Breeding and scientific advances in the fight against Dutch elm disease: Will they allow the use of elms in forest restoration?
}

\author{
Juan A. Martín ${ }^{1} \cdot J_{u a n}$ Sobrino-Plata ${ }^{1} \cdot$ Jesús Rodríguez-Calcerrada $^{1}$ \\ Carmen Collada $^{1} \cdot$ Luis Gil $^{1}$
}

Received: 31 December 2017 / Accepted: 3 April 2018 / Published online: 17 April 2018

(C) The Author(s) 2018, corrected publication June 2018

\begin{abstract}
Elms (Ulmus spp.) were once dominant trees in mixed broadleaf forests of many European territories, mainly distributed near rivers and streams or on floodplains. Since ancient times they have provided important services to humans, and several selected genotypes have been massively propagated and planted. Today elm populations are severely degraded due to the negative impact of human-induced changes in riparian ecosystems and the emergence of the highly aggressive Dutch elm disease pathogens. Despite the death of most large elm specimens, there is no evidence of genetic diversity loss in elm populations, probably due to their ability to resprout after disease. The recovery of elm populations from the remaining diversity should build from genomic tools that facilitate achievement of resistant elm clones. Research works to date have discerned the genetic diversity of elms and are well on the way to deciphering the genetic clues of elm resistance and pathogen virulence, key findings for addressing recovery of elm populations. Several tolerant clones suitable for use in urban and landscape planting have been obtained through traditional species hybridization with Asian elms, and various native clones have been selected and used in pilot forest restoration projects. Successful reintroduction of elms should also rely on a deeper understanding of elm ecology, in particular their resilience to abiotic and biotic disturbances. However, all these efforts would be in vain without the final acceptance of elm reintroduction by the social actors involved, making it necessary to evaluate and publicize the ecosystem services elms can provide for today's society.
\end{abstract}

Keywords Ulmus $\cdot$ Dutch elm disease $\cdot$ Ophiostoma novo-ulmi $\cdot$ Restoration $\cdot$ Breeding

The original version of this article was revised due to a retrospective Open Access order.

Juan A. Martín

juan.martin.garcia@upm.es

1 Departamento de Sistemas y Recursos Naturales, ETSI Montes, Forestal y del Medio Natural, Universidad Politécnica de Madrid, Ciudad Universitaria s/n, 28040 Madrid, Spain 


\section{Introduction}

Dutch elm disease (DED) is one of the first illustrations of how introduction of alien pathogens can globally threaten the ecological role and functions of keystone native forest species. The enormous disturbance caused by DED pathogens resulted in large economic losses and the abandonment of elm use in forest, landscape and urban planting. Many efforts have been made in the last 100 years to understand the disease and all its components, and to obtain elm cultivars capable of resisting or tolerating the disease. The aim of this review is to provide insight into achievements in the technological and scientific fight against the disease, focusing on the situation of European elms, particularly the field elm (Ulmus minor Mill.). This is the European elm species most harmed by DED pandemics and has therefore has been the subject of much research and breeding. The review also examines the scientific and technological advances made in North America as a consequence of the major impact of DED on American elms. It includes examples of pilot reforestation projects with tolerant native elms currently being implemented in Spain as part of a European LIFE + project. The review concludes with a discussion of whether recovering elm populations to their pre-DED stage is still feasible and if we are ready to begin largescale elm restoration activities with resistant elms.

\section{Elms before and after the emergence of Dutch elm disease}

\section{Ecological and cultural role of European elms before DED outbreaks}

Elms were once keystone forest trees in mixed broadleaf forests of most European territories, mainly distributed near rivers and streams or on floodplains. They frequently exerted a dominant role in the forest and sustained valuable species richness (Richens 1983). The three elm species native to Europe (Ulmus glabra Huds., Ulmus laevis Pall. and U. minor) are all highly susceptible to infection by DED pathogens but show different degrees of damage in the field (Collin et al. 2000). The scarcity of DED insect vectors at northernmost latitudes in the case of $U$. glabra and the unattractiveness of $U$. laevis to insect vectors have allowed many populations of these species to remain unaffected by the disease or at least avoid severe degradation.

Ulmus glabra (wych elm) is the most abundant European elm at northern latitudes. It is adapted to hemiboreal and temperate climates and grows well in moist forests with rich soils and high humidity or in groves beside streams, but not in flooded or very humid soils. It usually occurs in mixed broadleaf forests, and in the southern range of distribution it is almost exclusively found in mountain areas (Collin et al. 2000), which is why it is called "mountain elm" in these regions. Ulmus laevis (European white elm) is a riparian tree usually distributed along large European rivers in central and eastern Europe. Small fragmented populations of this species are also found in Spain and southern France, beside streams and rivers and in endorheic basins and seasonal wetlands (Venturas et al. 2015). Molecular studies of the genetic diversity of southern populations for comparison with central European populations concluded that the Iberian Peninsula was probably a glacial refuge for the species (Fuentes-Utrilla 2014). This species thrives in damp, periodically flooded soils, preferring slightly acidic and siliceous soils. The third native elm, $U$. minor (field elm), is more abundant at southern latitudes. It is found naturally in riparian 
forest beside rivers and streams and prefers calcareous soils. Before the DED pandemics it frequently had a dominant role in the forest (Mackenthun 2000). It is also found thriving in areas farther away from river banks, influenced by aperiodic floods. In the Iberian Peninsula, this species is adapted to tolerate poor soils and a certain level of water deficit in summer, which allowed widespread planting of $U$. minor in many urban and landscape areas. Today adult $U$. minor populations have virtually disappeared from most areas of their natural distribution. Before the introduction of DED pathogens, European elms coexisted in close association with a large number of organisms, from microorganisms to insects (Richens 1983). The Dutch botanist and driver of elm breeding in The Netherlands since 1953, Hans M. Heybroek reported that in a single area in Europe 79 insect species were specialized on elms (Heybroek 1993a), indicating the important contribution of this tree to biodiversity.

Apart from their ecological value, elms have considerable cultural value. Historical knowledge has been decisive in unraveling the taxonomic complexity of the genus (see following section), because studies with molecular markers required history to understand the evolutionary past of European elms in recent millennia. Among other ecosystem services, elms provided humans with good quality wood. Hesiod (8th century BC) advised farmers to make their plow rudders with elm wood because it was the safest material (PérezJiménez and Martínez-Díez 1978). The botanist Theophrastus (4th century BC) noted that elm wood was not prone to warping and rot. He highlighted its use in sumptuous doors and shipbuilding, where it was found in the frames, the keel and the anchor beams (Hort 1916). Varro (116-27 BC), in his De Re Rustica (Hooper and Ash 1934), was the first to record the role of elms as support for vines, which were entwined around trees. Cato (95-46 BC), a member of the Roman aristocracy linked to the land, recommended elms for fencing properties, feeding cattle and building wine presses or casks. The agronomist Columela (4-70 AD), born in Cádiz (Spain), recognized two species of elms: the local elm and the species from Gaul or "Atinia" (alleged to have originated in Atina, in Lazio, Italy), which he noted reproduced only from cuttings (Holgado-Redondo 1988). For vine supports he recommended the elm, especially the Atinia (Foster and Heffner 1954). Its leaves provided good winter pasture for oxen and rams, its seeds could be used for raising goats and the bark was useful for curing fever in pigs. He also noted that this species was capable of growing in many soil types. When Columela planted his vineyards in Cádiz (Spain) (Tovar 1975), he used the Atinia elm he had brought from his property in Lazio. Palladium, a 4th century AD agronomist, recommended elms as support for vines in his Opus agriculturae (MoureCasas 1990). As a result of this practice, which continued into the 19th century in Spain and the 20th century in Italy, a tree linked to rivers in nature but able to live in mediocre soil spread throughout the Roman empire. The increase in its area and mixing with native populations disfigured its natural area of distribution and facilitated miscegenation with spontaneous populations. The significant cultural use of elms in wine production and as winter fodder led Hans Heybroek (2015) to refer to the elm as "the tree of milk and wine".

In modern times elms are no longer used to support vines, after the development of lowtrained-vine systems. Elms became urban trees because of their luxuriance and beauty, lack of specific soil type requirements, ability to resist winds and recover from mechanical damage, capacity as a riparian tree to thrive in soils with poor oxygenation, tolerance to soil compaction, and easy propagation by root and aerial cuttings (Buiteveld et al. 2015). They provided shade and cooler temperatures for public gathering places and water wheels, and protected animals from summer heat. Their longevity made them a feature of the places where they were planted. The cultural importance of elms in the past is manifested today in the numerous town squares, avenues and toponyms in which the name of this tree appears. 


\section{Taxonomic complexity of European elms}

The genetic diversity of forest species is not usually uniform throughout their distribution range, because it is affected by factors such as natural selection, mutation, migration, genetic drift and domestication by humans. In forest restoration, it is important to address the genetic structure of the forest to predict and evaluate the effects of biotic or abiotic disturbances. European elms are divided into two sections. The first of these, Blepharocarpus, is represented in Europe by $U$. laevis, which possesses easily recognizable morphological traits and does not hybridize with other European species (Mittempergher and La Porta 1991). However, the taxonomy of the second section, Ulmus, appears to be more complex, and arguments such as tree morphology, hybridization capacity, reproductive strategies and the impact of humans on dispersal have led to a range of theories. The simplest and most widely accepted classification was proposed by Richens (1983), who recognized two species, U. glabra, and U. minor Mill. sensu latissimo, although other authors suggested dividing the $U$. minor complex into several species and subspecies (e.g., Melville 1975; Armstrong 1992; Armstrong and Sell 1996).

The development of genetic markers opened up the possibility of understanding the recent history of European elm species. Hollingsworth et al. (2000) showed that Ulmus plotii Druce (Plot's elm) and U. minor ssp. angustifolia (Cornish elm), classified by Richens within the $U$. minor complex, are single widespread clones in Britain that lack the status of species or subspecies. These findings support the hypothesis of Richens (1983), who argued that the variation found within the $U$. minor complex was strongly influenced by human propagation and the spread of specific cultivars since ancient times. In the 2000s, researchers from the Spanish elm breeding program began a study of the evolutionary history of European elms. Chloroplast DNA markers, which are maternally inherited, were used to study the diversity of U. minor and U. glabra populations from Greece, Italy, France, Spain and Britain. Four main haplotype lineages were established: A in Greece, B in northern Italy, C in Italy, Spain and Britain, and D in Spain, France, northern Italy and Britain (Gil et al. 2004). Lineage D corresponded to both $U$. minor and $U$. glabra, while lineage $\mathrm{C}$ was observed only in $U$. minor in Spain and Britain but in both species in Italy, suggesting that haplotype $\mathrm{C}$ had an Italian origin. Analysis with nuclear microsatellites revealed a widely distributed clone within lineage-C elms whose close genetic similarity to samples from Latium (Italy) reinforced the idea that its origin was Roman (Gil et al. 2004). With historical knowledge it can be assumed that this clone was the Atinia elm described by Columela, who introduced it into Spain after inheriting family properties. Lineage $C$ was widespread throughout Spain, from where it was introduced into England and became so popular that it was classified as a single species, Ulmus procera Salisb (English elm). In other Spanish locations, trees with chloroplasts of lineage $\mathrm{C}$ other than the Atinia genotype were identified, pointing to its introduction into Spain as vine support before Columela's era. Buiteveld et al. (2016) applied nuclear microsatellites to study Dutch U. minor populations and compared them with reference collections from Belgium and France. They found high levels of clonality in the Dutch field elm populations and sharing of clones between locations up to $70 \mathrm{~km}$ apart, indicating human-mediated translocations of elm cultivars. Two Dutch genotypes were also found in the Belgian collection, supporting the hypothesis of significant anthropogenic influence in the distribution of this species.

The development of molecular markers, in combination with historical knowledge, has made it possible to decipher the taxonomy and genetic diversity of European elms. 
It is evident that certain elm varieties were massively propagated in the past through asexual methods and planted in geographically distant parts of Europe. The expansion of certain varieties was linked to cultural practices, mainly for use as vine supports, cattle fodder and ornamentals. The impact of elm domestication on the outcome of the DED pandemics is difficult to define, but disease spread may have been accelerated in areas with high levels of elm clonality.

\section{Impact of DED introduction on elm populations}

European elm populations are now severely degraded owing to several concurrent circumstances. Elms have frequently occupied land with optimal agricultural yield, excellent fertility and good irrigation. This encouraged humans to establish horticultural crops, pastures or productive forest plantations in these locations, leading to the decline of riparian forests (Mackenthun 2004). Other contributing factors in this decline include soil drainage, hydrological control of rivers and overexploitation of aquifers. But elms have also suffered DED pandemics. This vascular disease has had a devastating impact worldwide and is one of the worst plant diseases ever known. Mackenthun (2013) quantified elm losses and their causes in two floodplains in Saxony (Germany) and concluded that human impact may have devastated $90 \%$ of original elm habitats, while DED accounted for another $90 \%$ of the remaining population. Therefore, today we see just $1 \%$ of what once were floodplains dominated by elm.

Three pathogens in the genus Ophiostoma are known to cause DED symptoms in elms: Ophiostoma ulmi Buissman Nanf., which led to the first pandemic; O. novo-ulmi Brasier, more virulent than the former and causal agent of the second pandemic; and O. himal-ulmi, a DED pathogen endemic to the Himalayas in balance with the local elm and bark beetle population (Brasier 2000a). The disease emerged with the movement of wood products across the globe at the beginning of last century, which propitiated the introduction of $O$. ulmi into Europe, North America and central Asia. East Asia was its most probable native range (Masuya et al. 2010). Ophiostoma novo-ulmi, causal agent of the second pandemic, appeared more or less simultaneously in Eastern Europe and North America around 1940. Apparently better adapted to a temperate climate and with ability to secrete higher amounts of the hydrophobin ceratoulmin, this second pathogen spread rapidly in Europe, replacing O. ulmi and causing massive elm losses. Ceratoulmin has been proposed to act as a parasitic fitness factor, which increases the capacity of conidia to adhere to the exoskeleton of bark beetles (Temple et al. 1997). In North America, the impact of the second pandemic has been less evident due to the greater susceptibility of American elms to O. ulmi. Globalization has exponentially increased the number of invasive forest pathogens in the last few decades (Santini et al. 2013): ash dieback is a more recent example of a forest disease threatening European populations (Gross et al. 2014) and resembles DED in its virulence. The introduction of DED into Europe and North America devastated already degraded riparian elm populations.

After the arrival of DED pathogens, native bark beetles in the genus Scolytus (Curculionidae: Scolytinae), which breed in the inner bark of decayed or dying elms, became the most efficient vectors of the disease. The pathogen develops well inside the insect's breeding galleries, where it reproduces either sexually or asexually and produces spores (conidia and ascospores). When the adult insect emerges from the pupal chamber and flies to a healthy elm for feeding, fungal spores attach to its body. Host preference in this phase appears to be mediated by plant chemicals detected by the insects that are characteristic of each species or even plant genotypes within a species (Pajares et al. 2004; Anderbrant 
et al. 2017). It has been shown that elm bark beetles prefer $U$. minor to $U$. glabra and $U$. laevis (Webber 2004) and therefore DED transmission is more effective in $U$. minor. Once a healthy tree is identified and accepted, the insect feeds in the phloem of twig crotches and branches. During maturation feeding, spores are transmitted to the phloem tissues, where they germinate (Webber 1987). Spores could be also transmitted directly into vessels if the feeding groove penetrates into the vascular system. The developing hyphae colonize the vascular tissue of the tree. The tree reacts to infection by a massive blocking of vessels with tyloses which, together with fungal metabolites, induces embolisms in functional vessels. These processes cause leaf yellowing and wilting of branches, ultimately killing the tree (see "Physiological factors predisposing to and being altered by DED: integration with anatomical and chemical factors" section). During the DED pandemics the weakening of elm trees increased the availability of suitable plant material for beetle breeding, leading in turn to an exponential increase in the beetle population.

Since the DED pandemics, the European elms have lost their roles of dominant riparian forest trees (U. minor and $U$. laevis) and of important components of mixed forests (U. glabra $)$ and are used only scarcely in forest restoration or urban planting. However, the field elm survived in many locations because of its considerable ability to sprout and produce root suckers, even though young trees show recurrent DED symptoms once they reach 3-5 $\mathrm{m}$ in height (Fig. 1). This situation is similar to a report for a $U$. glabra stand in western Great Britain, where dominant individuals were severely affected but a large high-turnover subpopulation of fast-growing and repeatedly diseased seedlings and sprouts appeared in the understory (Peterken and Mountford 1998). A similar situation was described in a wych elm population in southern Sweden (Oheimb and Brunet 2007) and in American elms in North America (Parker and Leopold 1983). In Denmark, Nielsen and Kjaer (2010a) described patches of juvenile $U$. glabra trees in the forest, possibly indicating reestablishment of $U$. glabra by seedlings combined with resprouting from stumps of previously infected trees, interspersed with occasional old trees. This indicates that despite

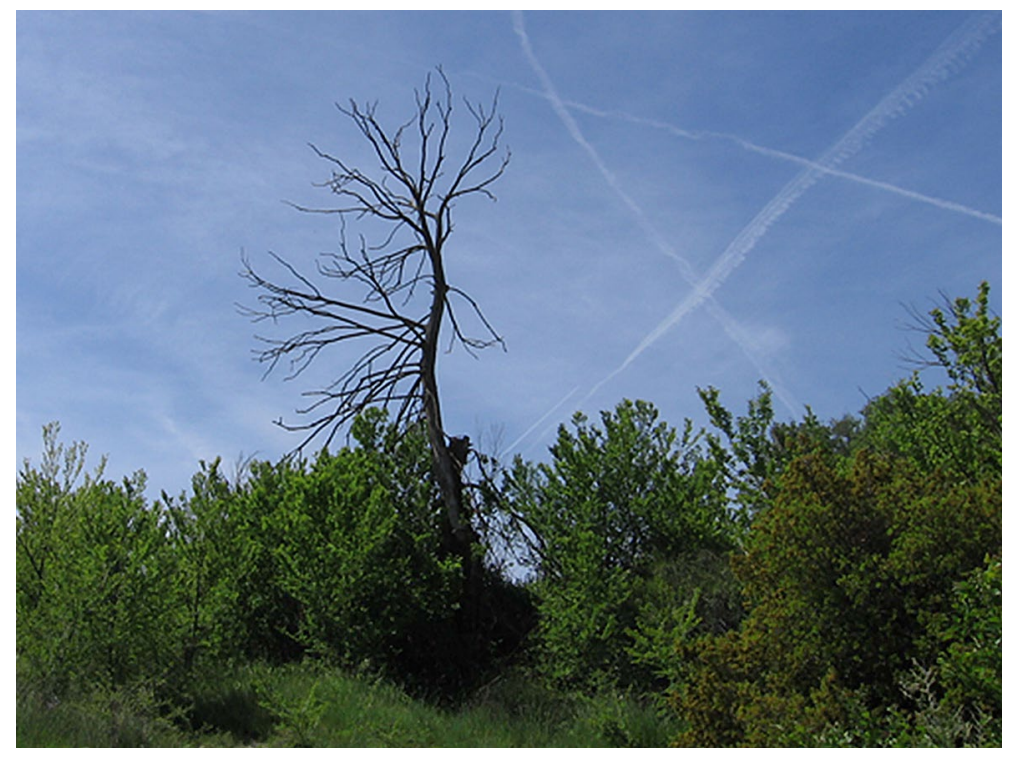

Fig. 1 Profuse Ulmus minor sprouts growing around a tree killed by DED in Spain 
the disappearance of most large specimens of European and American elms, the risk of extinction of these elm populations can be considered low.

The risk of genetic diversity loss in elm populations globally is uncertain and probably depends on their degree of fragmentation and isolation in the long term. Several studies have suggested there is no evidence of genetic diversity loss in elm populations as a consequence of the DED pandemics. Buiteveld et al. (2016) found no evidence of genetic impoverishment in Dutch $U$. minor populations. In the United States, no evidence of genetic diversity loss was found in five Ulmus rubra Muhl. populations in Wisconsin when they were compared with 77 pre-DED herbarium specimens (Brunet et al. 2016). The authors argued that population sizes common for most forest trees (even those suffering substantial mortality) and the high gene flow characteristic of wind-pollinated trees appear sufficient to maintain considerable levels of genetic diversity in the species. Bertolasi et al. (2015) found that pollen dispersal distances in U. minor are large (up to $8 \mathrm{~km}$ ), maintaining genetic connectivity among isolated individuals and stands. Nielsen and Kjaer (2010a) reported that isolated individuals of $U$. glabra in Denmark are important to maintain high genetic flow despite the elimination of thousands of large trees by DED. These authors found no indications of loss of alleles due to random genetic drift at the examined loci in whole stands or isolated trees. They argued that this was not surprising, because the bottleneck caused by the disease is very recent and the generation time of elm trees is long. Genetic consequences of fragmentation can therefore be more delayed than ecological effects (Bertolasi et al. 2015). In U. laevis, however, a lower level of polymorphism than typically found in other comparable tree species has been identified (Whiteley 2004, Nielsen and Kjaer 2010b), although DED is unlikely to have any responsibility in this phenomenon. Fuentes-Utrilla et al. (2014) attributed this circumstance to bottlenecks in southern populations of $U$. laevis as a consequence of natural population fragmentation associated with Holocene expansion of more xeric habitats in the Iberian Peninsula, while in central Europe it may have resulted from intense and historically recent anthropogenic landscape transformation.

Conserving substantial genetic diversity is essential to design long-term strategies for the recovery of natural or semi-natural populations and will make breeding advances possible. The survival ability of certain populations of large trees seems to be highly dependent on local environmental conditions, because disease progression appears to be abnormally slow in some cases (e.g., Martín et al. 2010; Coleman et al. 2016). Tree resilience appears to originate from complex interactions among the pathogen strain, the host genotype, the symbiotic flora living in host tissues, climate conditions and the insect vectors. Despite local survival of some elm populations, the overall condition of European and North American elms can be regarded as severely degraded because of the almost total loss of their ecosystem functions and services, although research and breeding advances have the potential to improve this situation.

\section{Breeding advances against DED}

Traditional breeding is still considered the most consistent alternative to combat DED. However, the importance of sanitation and preventive injections of systemic chemical fungicides or biological control agents (see "Biological control in the fight against DED" section) as part of an integrated control of DED in urban forestry should be acknowledged. Other control strategies, such as spraying against bark beetles, have been ineffective or are largely unacceptable due to health and environmental concerns. 
Breeding efforts began soon after the introduction of DED. In 1928, the first breeding program was initiated in The Netherlands to combat the first DED pandemic caused by O. ulmi (Buisman 1928) (Fig. 2). The massive presence of the cultivar Ulmus $\times$ hollandica (U. glabra $\times U$. minor) in The Netherlands and the efforts made to study the disease justified the name "Dutch elm disease". The Dutch government commissioned pathologists Johanna Westerdijk and Christine Buisman, at the Willie Commelin Scholten Phytopathological Laboratorium, in Baarn, to study the disease detected in 1917 (Heybroek 1993b). They visited Madrid (Spain) in the spring of 1934 to verify the presence of the mycosis (Benito 1936). Johanna Westerdijk was a friend of Van Eeghen, the Dutch owner of an estate in Madrid known as Quinta de la Fuente del Berro, from where a batch of seeds was collected in 1929. After the seedlings had grown, susceptibility tests to $O$. $u l m i$ were performed and the first elm tree tolerant to the disease was selected and named Christine Buisman in honor of the researcher, who died in 1936 at the age of just 36 . In 1937 this clone, of the species $U$. minor, was released onto the market, but because of poor adaptation to sea winds and the fungus Nectria cinnabarina (Tode) Fr., it was withdrawn in The Netherlands (Heybroek 1993b). In 1953 Hans Heybroek took up the work begun at the Willie Commelin Scholten Phytopathological Laboratorium and transferred it to the Dorschkamp Research Institute, in Wageningen. In the final stage, the Dutch program focused on hybridizing native elms with resistant Asian species. The objective was to obtain progenies combining the DED resistance of Asian species with the local adaptability and superior growth and ornamental qualities (according to European standards) of native elms. Subsequent backcrosses based on ornamental characters determined the selection of elms for urban use. Several elm cultivars obtained in The Netherlands with a moderate to good level of resistance are available on the market, and Alterra (Wageningen University \& Research) is conducting adaptability trials on various unreleased clones (Buiteveld et al. 2015). Some of the first cultivars released by the Dutch program, such as Commelin, included only European

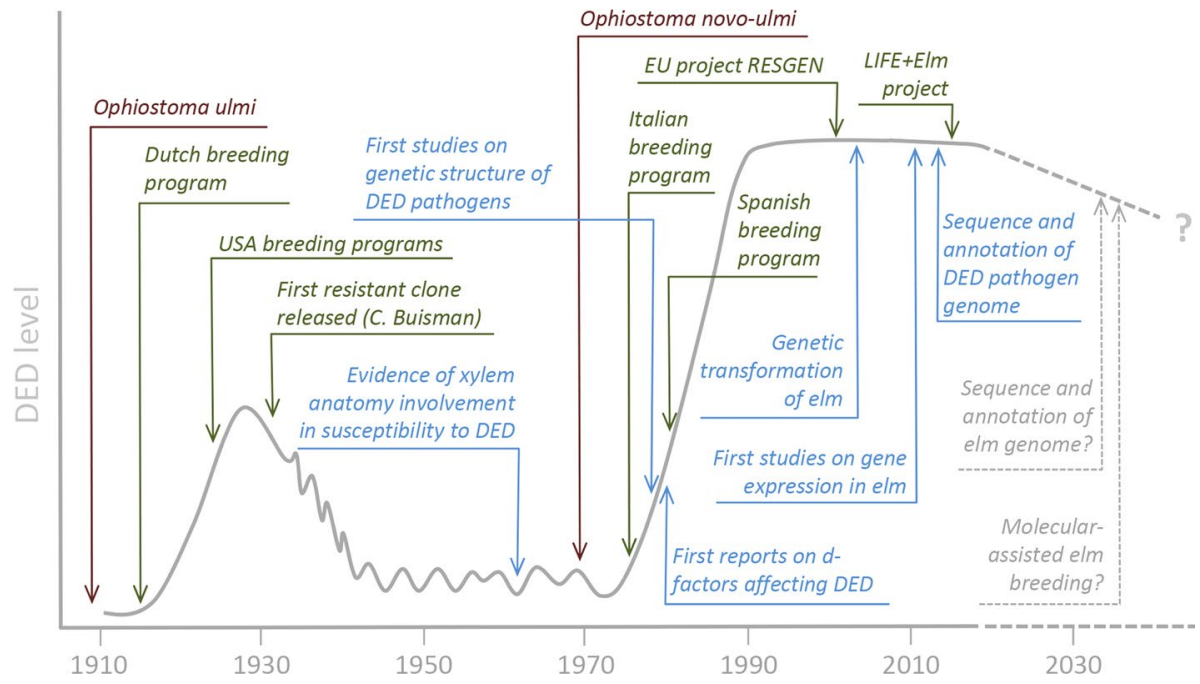

Fig. 2 Some key breeding and scientific advances in the fight against DED in relation to the approximate impact and chronology of the two DED pandemics in Britain and northwest Europe (from Brasier 1996; grey line). Dashed lines indicate advances with potential to reduce DED impact in the future 
parentage and were selected because of their good resistance to the first DED pathogen $(O$. ulmi), but were later affected by $O$. novo-ulmi. However, other cultivars, mostly first or second generation hybrids with the Himalayan elm (Ulmus wallichiana Planch.), showed good levels of resistance to $O$. novo-ulmi. One of the best-ranked cultivars for resistance is the Columella clone, an offspring of Plantijn, a hybrid clone with $25 \% \mathrm{U}$. wallichiana parentage (Heybroek 1993b). The improved resistance shown by the most recently released cultivars could be a result of increased use of Asian germplasm in recent decades. However, some recent Alterra selections, such as clone 1304, have parentage with only $U$. glabra and U. minor, demonstrating that disease resistance can be improved by complex hybridizations between native species (Buiteveld et al. 2015).

The Dutch program paved the way for other breeding programs in Europe and provided them with valuable starting materials and a methodological reference. The Italian and Spanish programs began in the 1970s and 1980s, respectively, in response to the second and more aggressive DED pandemic, caused by O. novo-ulmi (Fig. 2). The Institute of Plant Protection of the Italian National Research Council (CNR), in Florence, initiated the Italian program with the main objective of obtaining resistant cultivars well adapted to the Mediterranean climate. Native elm species and resistant selections from the Dutch program were crossed with Asian elms showing good adaptability to the Mediterranean area, such as Siberian elm (Ulmus pumila L.) (Santini et al. 2012). Crossability of elm species from different taxonomic sections was evaluated (Mittempergher and La Porta 1991). Santini et al. (2012) reported more than 50,000 hybrid seedlings tested in Italy, with around 80 individuals showing good resistance scores. As a result of these breeding efforts, five resistant clones were patented and released onto the market. Mittempergher and Santini (2004) noted that one interesting aspect of the Italian program was that introduction of non-native elm species may entail risks of susceptibility to local parasites of minor importance to native species, such as elm yellows or the elm leaf beetle, Xanthogaleruca luteola Müller.

The Spanish program initiated in 1986 thanks to an agreement between the Technical University of Madrid (UPM) and the Spanish Environmental Administration. The program began with a search for native genotypes that had survived the DED pandemics. Among these, U. minor $\times U$. pumila hybrids were frequently observed. Ulmus pumila, which hybridizes easily with U. minor (Cogolludo-Agustín et al. 2000; Brunet et al. 2013), is assumed to have been present in Spain since the 16th century (Gil et al. 2003). Hybrids were also used as starting material in breeding activities in Spain. As a result of breeding activities, several resistant unreleased hybrids with 50 or $25 \%$ of $U$. pumila germplasm were obtained (Solla 2000). However, public opinion in Spain was very critical of exotic species and transgenic plants and this view gathered force among environmental groups in later decades. The success of the program relied on finding tolerance in native germplasm. Therefore, in the 1990s, the Spanish program included native elms in the susceptibility trials and in the following decade focused mainly on selecting native tolerant elms. After two decades of resistance trials in Spain, seven clones tolerant to DED and morphologically classified as U. minor were registered in 2013 in the National Catalog of Forest Reproductive Base Materials (Martín et al. 2015a). Research is in progress to determine whether the genetic background of these selections contains U. pumila genes. Interestingly, breeding carried out in the Spanish program showed that resistance to DED is primarily transmitted from the mother (Solla et al. 2015), in agreement with previous research (Townsend 1979). It was also shown that there is a high degree of additive genetic control of resistance, indicating the effectiveness of selection for DED resistance and rapid tree growth (Solla et al. 2015). 
Further breeding efforts have been conducted in other European countries to evaluate adaptability and disease resistance of Dutch and other elm cultivars, particularly France (Mittempergher and Santini 2004). A European Union (EU) project (RESGEN 78, 1997-2001), coordinated by INRA (France), was implemented to boost static and dynamic conservation of elm genetic resources in Europe (Collin et al. 2000). Collaboration among the groups allowed breeding programs to gather material from very different provenances.

Considerable breeding advances against DED have also been made in North America (Marcotrigiano 2017; Knight et al. 2017). Breeding activities in the United States started in 1933 after an agreement was made between Cornell University and the Boyce Thompson Institute (Sinclair et al. 1974). This initial effort was followed by programs with a longer duration. The Agricultural Research Service of the United States Department of Agriculture (USDA-ARS) has extensive experience in breeding $U$. americana, which is complicated by the extremely high susceptibility of this species to DED and hybridization barriers with potential donor species (e.g. Asian elms). Despite these difficulties, several U. americana cultivars with high disease tolerance were released onto the market (Mittempergher and Santini 2004 and references therein). Significant progress was made in this program by crossing Eurasian elm cultivars to find tolerance to DED and elm leaf beetle (Townsend and Santamour 1993), providing new insight into the inheritability of resistance in elms. A number of resistant selections were released onto the market. Further advances in breeding American elms have been made at the University of Wisconsin, which produced the "American Liberty Multiclone", comprising six genotypes showing good levels of tolerance to O. ulmi (Smalley et al. 1993). Several tolerant cultivars obtained by crossing Asian elms were released onto the market. The Morton Arboretum, in Chicago, began a third breeding program in the United States (Ware 2000) crossing Eurasian elms to produce resistant elm cultivars and compiling a collection of elms from China with good tolerance levels for use in breeding.

Breeding efforts in Europe and North America since 1928 have provided more than 20 clones with good to very good tolerance to DED that are available on the market, and new promising unreleased varieties are awaiting adaptation trials. Mostly obtained by crossing and backcrossing native and Asian elm species, these clones are primarily intended for use in urban forestry. However, several promising native clones with good tolerance to DED have emerged in recent years (Martín et al. 2015a), opening up the possibility of a future use of elms in reforestation of natural or semi-natural stands. But before this becomes widespread, it is necessary to address the adaptation of these clones to different environments and potential ecological barriers and increase the genetic diversity of tolerant clones through new breeding cycles. Resistance to DED is strongly believed to be polygenic (Townsend 2000; Aoun et al. 2010), but it remains unclear which plant genetic traits confer resistance to $O$. novo-ulmi or how many genes are involved and where they are located in the genome. Although this lack of knowledge slows progress in elm breeding, considerable advances are being made with the application of genomic tools, as explained in the following section. 


\section{Scientific advances to understand and manipulate resistance to DED}

\section{Physiological factors predisposing to and being altered by DED: integration with anatomical and chemical factors}

DED is one of the most widely researched forest diseases worldwide (Fig. 3). Vascular wilt syndrome DED is mostly associated with xylem hydraulic failure and possibly dysfunction of cambium and parenchyma in chronic phases of the disease (Ouellette and Rioux 1992). Within days or weeks of inoculation with DED fungi, there is a decrease in sap flow, leaf water potential, transpiration, photosynthetic capacity and/or nonstructural carbohydrate concentrations, associated with the embolization of outermost, current-year xylem vessels transporting most of the sap (Newbanks et al. 1983; Oliveira et al. 2012; Li et al. 2016; Beier et al. 2017). Progressive fungal invasion of sapwood causes complete failure of the hydraulic system, which kills a large part of the crown and eventually results in stem dieback. If the root system remains alive, root carbon reserves can be remobilized to resprout and trees sometimes experience cycles of resprouting and dieback for decades (Peterken and Mountford 1998). Xylem dysfunction is caused by tyloses, gels, gums and other compounds of host and pathogen origin that increase sap viscosity, clog pit membranes and occlude vessels (van Alfen and Turner 1975; Newbanks et al. 1983; Ouellette and Rioux 1992).

In tolerant elm species, hybrids or genotypes, inoculation with DED fungi causes little alteration in plant function and few DED symptoms. The exact reason for this is unknown despite numerous investigations, possibly because many investigations were based on interspecific elm comparisons, rather than intraspecific comparisons between resistant and susceptible clones. In general, results point to more effective restriction of the pathogen

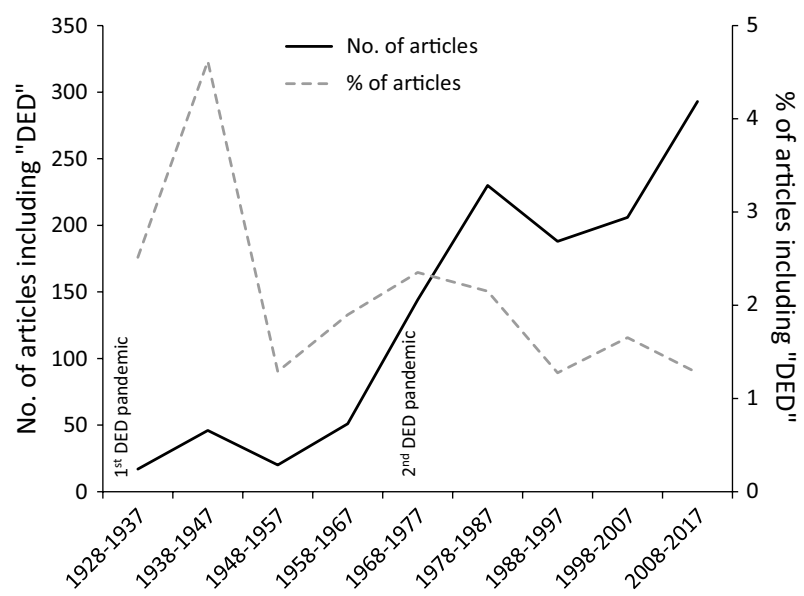

Fig. 3 Chronology of the number of scientific articles related to research on DED recorded in the Web of Science in the last 90 years. Solid line: total papers containing "Dutch elm disease" in the topic (vertical scale on the left). Dashed line: percentage of papers containing "Dutch elm disease" in relation to total papers containing "tree" and "pathogen" in the topic (vertical scale on the right). The total number of works about DED has grown during this period, but an opposite trend is observed in the percentage scale (dashed line). Two publication peaks are evident (dashed line): the first in 1938-1947, after the onset of the first DED pandemic, and the second in 1968-1977, after the onset of the second pandemic 
in some elm species, hybrids or genotypes in comparison with more susceptible counterparts (Fig. 4). High constitutive or rapidly inducible production of antifungal and occlusive chemical compounds (phenolic compounds, pectin, suberin, lignin, mansonones...) contributes to localize the pathogen near its entry point at the cost of proportionally few blocked vessels (Ouellette and Rioux 1992; Duchesne 1993; Martín et al. 2008, 2013). The differences in numerous xylem characteristics between tolerant individuals and susceptible ones are probably related to slower propagation of the pathogen in the former. Lower vessel grouping, vessel diameter, proportion of large vessels, pit membrane diameter and pit abundance per vessel-wall area directly restrict pathogen axial and radial spreading (McNabb et al. 1970; Solla and Gil 2002a; Martín et al. 2009) and indirectly restrict spreading by favoring early closure of stomata in response to mild water stress that prevents bark dehydration (Pita et al. 2018). The combination of chemical, physiological and anatomical defenses helps to compartmentalize the pathogen, while initial fungal contention results in greater capacity to maintain fungal restriction later on due to lower declines in sap flow, bark water content, photosynthesis and energy available to fuel secondary metabolism. In contrast, over-production of tyloses, gums and gels can be responsible for complete vessel blockage and hydraulic failure (Morris et al. 2016). While the relationship of plant anatomical and chemical factors with DED resistance has been amply studied, the way these factors are related to each other and to plant physiology has received less attention. More research is needed to integrate the fragmentary knowledge of mechanisms apparently involved in DED resistance.

\section{Molecular advances to understand the genetic clues behind elm tolerance to DED}

The development of molecular tools and analysis of massive data have increased knowledge of many mechanisms associated with the regulation of processes occurring in plants (Bräutigam and Gowik 2010). The first genetic studies in elms were designed to solve population structure, conservation and taxonomic problems (e.g., Sherman-Broyles et al. 1992; Wiegrefe et al. 1994; Collada et al. 2004; Collin et al. 2004; Solla et al. 2005). Many recent works have increased the information available about molecular responses of elm species to DED pathogens (Bernier et al. 2015). Due to the difficulties of working with non-model species, these advances have been slower than similar works that have the advantage of widely described and validated sequenced genomes or transcriptomic studies (Rhee and Mutwil 2014).

Studies exploring the responses of Ulmus species to certain biotic and abiotic stresses have emerged only in the last decade. The first results in this field were obtained in two works using immunochemical detection of specific sequences in RNA extracts from two elm species, the DED-tolerant Ulmus pumila and the DED-susceptible U. americana (Nasmith et al. 2008a, b). In both studies the genes selected for analysis of their expression were those that codify for phenylalanine ammonia-lyase (PAL), a chitinase (CHT) and a polygalacturonase-inhibiting protein (PGIP). PAL is the first enzyme in the phenylpropanoid, flavonoid and salicylic acid biosynthesis pathways, which lead to the formation of secondary metabolites directly associated with defense responses in plants (Mauch-Mani and Slusarenko 1996). The other two are pathogenesis-related (PR) proteins that appear to counter pathogen attacks: chitinases are enzymes that degrade the chitin of fungal cell walls and PGIPs are proteins capable of inhibiting enzymes produced by pathogenic fungi (Van Loon et al. 2006). In an initial study, a tissue-dependent expression was observed in these genes (Nasmith et al. 2008a), which had similar expression levels in both species 
Fig. 4 A simplified tentative framework of DED tolerance mechanisms. After pathogen inoculation by elm-bark beetles, early detection and signaling occurs through reactive oxygen species (ROS) and different phytohormones. Constitutive traits (e.g. chemical profile and anatomical factors) together with constitutive and rapidly inducible production of antifungal and occlusive compounds delay radial, tangential and axial movement of the pathogen in DED-tolerant compared to DEDsusceptible elms. This incipient compartmentalization has a low impact on water transport and plant hydration, helping to maintain the synthesis of secondary compounds and effectively compartmentalize the infection. Under these circumstances, the cambium builds a suberized barrier zone that preserves xylem water transport, carbon gain, phloem transport and respiration, enabling the formation of new xylem components (i.e. new vessels, fibers and parenchyma cells replacing dead or malfunctioning cells) and allowing the tree to survive infection at chronic stages of disease. The arrow at the bottom of the figure represents a tentative temporal scale of the response to Ophiostoma infection. Triangles on pictures indicate the presence of antifungal or occlusive compounds in plant tissues

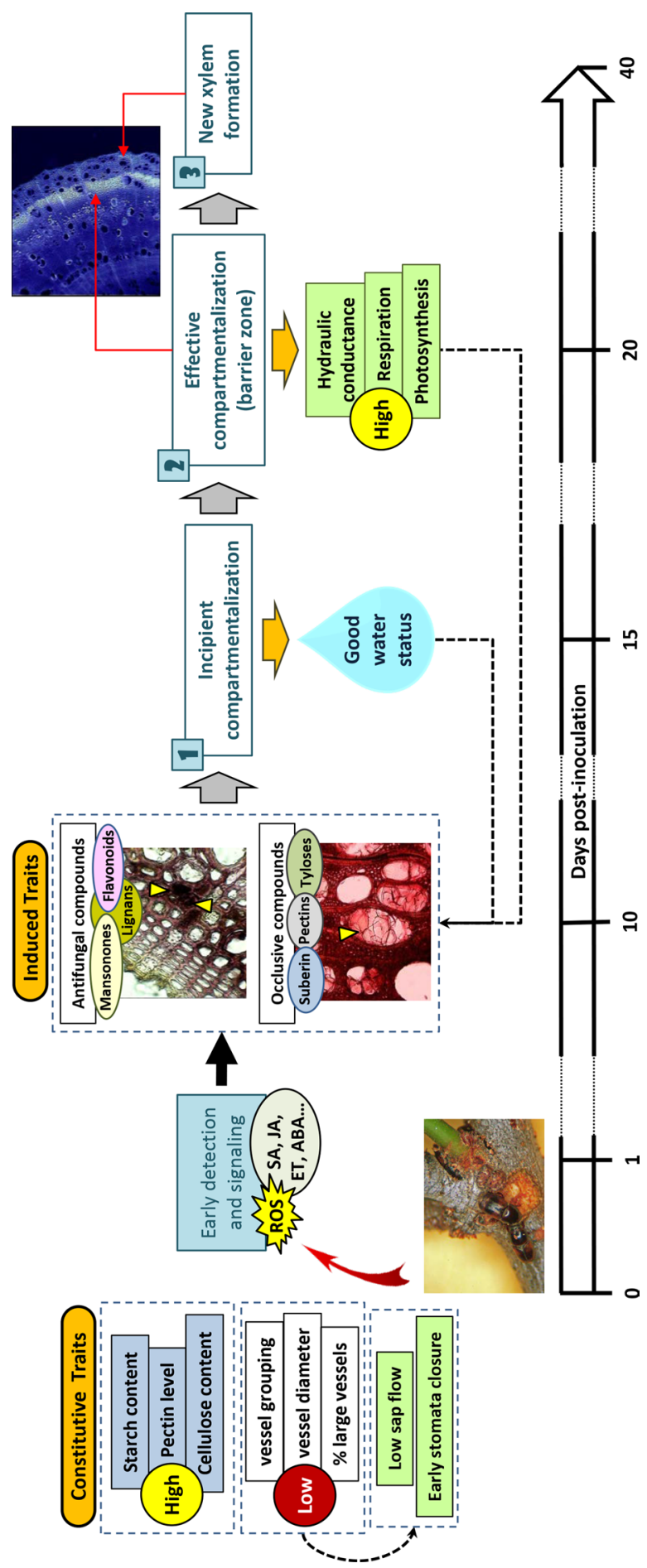


except for $P G I P$, whose expression was higher in $U$. pumila. In a second study, Nasmith et al. (2008b) analyzed the expression of these genes in $U$. americana leaf midrib in control and $O$. novo-ulmi-inoculated trees. Dot-blot analyses showed that $P A L$ increased its expression over time in pathogen-inoculated trees, while $C H T$ and $P G I P$ had a transient overexpression in these trees compared to controls. Aoun et al. (2009) used qRT-PCR to confirm the time-dependent $P A L$ overexpression in response to $O$. novo-ulmi in $U$. americana callus, as well as a relation between PAL expression and accumulation of phenols and lignin.

The emergence of new molecular methodologies opened new prospects in the study of DED resistance (Fig. 2). From 2010 to 2015, various works reported a growing number of genes identified in response to stresses in Ulmus spp. In 2010, Aoun et al. published a timecourse transcriptomic study in $U$. americana callus culture interacting with $O$. novo-ulmi. Analyzing expressed sequence tags (ESTs) during this interaction, the authors selected 296 unique transcripts that were upregulated in elm cells. These sequences were annotated and grouped into 20 functional categories, including the subcategories 'Plant-fungal specific systemic sensing and response', 'Disease, virulence, and defense', and 'Response to biotic stimulus'. After analysis, several genes appeared to increase their expression after $48 \mathrm{~h}$ and most coded for PR proteins or were implied in phenylpropanoid and phytoalexins biosynthesis pathways. A second EST database was obtained two years later in $U$. minor leaves artificially infected with elm leaf beetle eggs (Büchel et al. 2012). Various treatments were applied to U. minor leaves: egg laying and feeding by the beetle Xanthogaleruca luteola, only feeding by $X$. luteola, only egg laying and application of methyl jasmonate (MeJA). A much larger data resource was created with 52,823 unique transcripts by 454-pyrosequencing cDNAs obtained from leaves exposed to all treatments applied. The analysis revealed upregulation of genes encoding proteins involved in defense (chitinases, PR proteins and WRKY transcription factors), oxidative stress (Heat Shock Proteins, catalases and lipoxygenases), Jasmonic acid (JA) and terpenoids biosynthesis, JA-signaling and transport processes, and even in primary metabolism (carbohydrate, amino acid and fatty acid biosynthesis). In contrast, photosynthesis and growth-related genes appeared downregulated in this transcriptomic study.

Using the same methodology of massive sequencing, a de novo assembled transcriptome of $U$. minor was obtained from trees exposed to abiotic and biotic stresses (Perdiguero et al. 2015). The novelty of this work was the use of three $U$. minor genotypes with different degrees of tolerance to DED (one susceptible and two tolerant genotypes). The treatments also covered a wide range of responses: (i) drought, (ii) inoculation with O. novo-ulmi, (iii) inoculation with $O$. ulmi and (iv) inoculation with the endophytic fungus Daldinia concentrica. A total of 58,429 putative unigenes were identified, extending the limited information available at the time. Comparison of the sequences obtained with databases of other plant model species provided a good functional annotation of these unigenes, which were distributed into categories. The high number of unigenes associated with biotic or abiotic responses was noteworthy and included numerous MYB or WRKY transcription factors, dehydration-responsive element-binding proteins, leucine-rich repeat protein kinases, thaumatin-like proteins and disease resistance response proteins. Some of these genes were also orthologs of those found in $U$. americana in an earlier, smaller-scale work (Aoun et al. 2010). Two pathways were predominant in the analysis: "phenylalanine metabolism" and "alpha-linolenic acid metabolism", which are directly related to biotic stress responses because they are the pathways for biosynthesis of SA and JA, respectively (Pieterse et al. 2012).

Using the data from this transcriptome, a microarray experiment was designed and performed (Perdiguero et al. 2018). Atinian elms were inoculated in the trunk base with 
O. novo-ulmi and branch samples distal from the inoculation point were collected at different days post inoculation. This time-course assay revealed significant changes in gene expression of inoculated elms compared to control trees and was the first work of this magnitude to show the molecular response of $U$. minor during $O$. novo-ulmi invasion. A total of 1696 differential expressed genes (DEGs) were shown to be involved in the response to invasion. On the one hand, a clear systemic defense response mediated by SA was observed in these trees. Certain DEGs associated with the typical systemic acquired resistance (SAR) amply described in model plants (Ryals et al. 1996) were upregulated and increased their expression in a time-dependent manner. On the other hand, several DEGs were found downregulated over time. Genes associated with JA-signaling, auxin and gibberellin pathways or development and vegetative growth showed downregulation and suggested an antagonist effect of SA-mediated defense response to biological processes such as development, tissue differentiation, growth and JA-mediated defense response.

These studies revealed the importance of investigating DED responses in tissue both proximal to and distal from the inoculation point and also at different times, from the first hours to several days after inoculation, to extend knowledge of molecular responses to DED. Recent works have advanced in this direction: $U$. americana trees were inoculated with $O$. novo-ulmi and the expression of various defense-related genes was analyzed by RT-qPCR at different hours post-inoculation in samples collected near the inoculation point (Sherif et al. 2016, 2017). Unlike Perdiguero et al. (2018), these authors reported several JA-related genes overexpressed with the presence of $O$. novo-ulmi. However, the changes occurred at the inoculation point, indicating that local defense responses may be regulating differently from the responses in distal parts observed by Perdiguero et al. (2018). Brand new methodologies such as RNAseq could be accurate and promising tools to achieve the goal of fully understanding the molecular aspects of elm-Ophiostoma interactions.

Progress has also been made on the pathogen side. Many works have attempted to elucidate the virulence and population diversity of the Ophiostoma species. The first molecular studies of DED pathogens were performed in the 1980s to differentiate aggressive and non-aggressive strains of $O$. ulmi according to their protein and isozyme profiles (Jeng and Hubbes 1983; Bernier et al. 1983). In the 1990s, the first DNA-based studies were completed to characterize populations of O. ulmi and O. novo-ulmi (Jeng et al. 1991; Hintz et al. 1991; Bates et al. 1993; Hoegger et al. 1996). Later studies explained the genetic diversity of DED fungi populations, mainly in Europe and North America, and reported (i) higher diversification of DED fungi populations in Europe than in North America; (ii) coexistence of $O$. ulmi and $O$. novo-ulmi during the initial stages of the second pandemic and the presence of rare but transient hybrids between the two species in Europe (Brasier et al. 1998); (iii) rapid replacement of $O$. ulmi by $O$. novo-ulmi at each location; and (iv) rapid emergence of hybrids between the two subspecies of $O$. novo-ulmi, the European and North American races (Santini et al. 2005; Temple et al. 2006; Solla et al. 2008; Brasier and Kirk 2010). The genomes of $O$. ulmi and $O$. novo-ulmi were subsequently sequenced and annotated (Forgetta et al. 2013; Khoshraftar et al. 2013; Comeau et al. 2015), adding to information gathered earlier using traditional molecular methods. Insertional mutagenesis, analysis of genetic crosses and inspection of Ophiostoma spp. genomes revealed evidence about the function of some genes such as $\mathrm{Cu}$ (encoding the toxin cerato-ulmin, Bowden et al. 1994, 1996), Pat1 (encoding a pathogenicity factor, Et-Touil et al. 1999), Epg1 (encoding the enzyme endopolygalacturonase, Temple et al. 2009) and the presence of DNA transposons (Bouvet et al. 2007). More recently, extensive transcriptomic studies using an advanced molecular tool (RNAseq) have identified differential gene expression in 
the distinct phases of O. novo-ulmi from yeast to hyphae and mycelium (Nigg et al. 2015; Nigg and Bernier 2016).

\section{Use of genetic engineering (GE) in the search for resistant elms}

Genetically modified elms have been mentioned in few works, possibly due to the negative social impact and uncertain suitability of their use. Genetic engineering emerged as a plausible alternative in the fight against DED in the early 1990s. Bolyard et al. (1991) attempted to introduce foreign genes into calli of Ulmus 'Pioneer' using Agrobacteriummediated biolistic transformation. Although these experiments produced unsatisfactory results, they could be considered the starting point for the use of GE to enhance DED resistance. Dorion et al. (1995) reported the requirements for successful transformation of elms using Agrobacterium.

The most relevant advances in this field came from collaborations between the groups of Trevor M. Fenning and Kevan M. A. Gartland. From 1996 to 2005, several experiments aimed at transforming $U$. procera trees showed efficient introduction of reporter genes into several organs of the tree (Gartland et al. 2005). The first successes in transforming the English elm were achieved with strain B2.149 of A. tumefaciens (Fenning et al. 1996, 1997). However, transformation with this strain produced chimeric tumors containing transformed and non-transformed cells that resulted in shoots with aberrant morphology. The next attempt was with a disarmed A. tumefaciens binary vector, which provided considerably better results and achieved regeneration of morphologically normal English elms (Gartland et al. 2000). Another Agrobacterium-based system was tried in English elms with the aim of introducing modifications into their xylem structure that could restrict the establishment and movement of the DED fungus (Gartland et al. 2001). The introduction of different genes promoted changes in the internal vascular structure of regenerants, but also produced undesirable effects such as increased numbers of branches and shorter branch lengths.

Another methodology was used to transform Chinese elms (Ulmus parvifolia) by bombarding cell suspension cultures with gold particles coated with plasmids harboring resistance genes (Aziz et al. 2003). These obtained tissues showed correct transformation and later produced perfectly developed transgenic Chinese elms. The last report of transgenic elms was published in 2007. Four transgenic lines of $U$. americana were transformed with an antimicrobial peptide using Agrobacterium (Newhouse et al. 2007). ESF39A inhibits the growth of multiple bacterial and fungal pathogens in vitro (Powell et al. 2000). Although the peptide ESF39A produced by the transgenic elms inhibited in vitro growth of $O$. novoulmi, other tests performed with American elm sap showed a reduction in its antimicrobial activity. However, this work reported transgenic American elms capable of producing an antimicrobial peptide that could promote resistance to DED.

These works opened up the possibility of genetically modifying susceptible elms as an alternative to traditional breeding, but there appears to be no evidence of good performance of transgenic elms under field conditions. Genetic engineering of trees to confer resistance to fungal pathogens and insect pests could, however, provide an outstanding opportunity to address or mitigate the effect of native or invasive diseases (Häggman et al. 2016). Likewise, the convenience and decreasing cost of obtaining -omics data of nonmodel organisms and the development of new inexpensive tools for gene editing, such as CRISPR-Cas systems (Ledford 2015), will make these technologies available in more laboratories and for more plant species. Cisgenic approaches may gain broader social support 
than transgenics because they use genes from the same or closely related plant species, whereas transgenic approaches use genes from non-plant organisms or distantly related plants (Hou et al. 2014; Corredoira et al. 2016). Cisgenics have been considered similar to inter-species backcross breeding (Han et al. 2010). To advance in this direction, further progress is clearly needed in the search for candidate genes with resistance in elm species, e.g. by quantitative trait locus (QTL) studies.

\section{Biological control in the fight against DED}

As part of the strategy to combat DED through integrated pest management, numerous investigations have focused on potential methods to control propagation of the fungus both among trees via bark beetles (e.g. by maintaining beetle population at low size; O'Callaghan et al. 1980) or interconnected root systems (e.g. by stem girdling or mechanical isolation of individual root systems; Pajares Alonso and Martínez de Azagra 1990) and in infected trees (e.g. by branch pruning or application of antifungal compounds; Pajares Alonso and Martínez de Azagra 1990; Webber 1993). However, many of these methods have proven costly, unsuccessful and/or unfeasible for application to entire elm stands. Biological control has been proposed as a more cost-effective and environmentally clean alternative to traditional control methods (Scheffer et al. 2008). Biological methods could be used in restoration programs as a complement to breeding methods to strengthen the tolerance of restored populations to DED pressure.

Several O. novo-ulmi biocontrol methods have been investigated and have provided promising results under experimental conditions, although their practical application in the field has been limited. The method with greatest potential for large-scale application appears to be the use of mycoviruses called d-factors (Brasier 2000b). Several mycoviruses have been identified as highly host specific colonizers of O. novo-ulmi (Sutherland and Brasier 1995; Hintz et al. 2013). Many of them can severely reduce mycelial growth and sporulation of the pathogen, including reduced viability of the conidia and perithecial production (Brasier 1986). The biocontrol potential of d-factors relies on their ability to be transmitted among the $O$. novo-ulmi population in an epidemic area. D-factors can be freely transmitted by hyphal anastomosis between vegetative compatible colonies developing in the bark of weakened elms and can also be transmitted to asexual spores. The spread of d-factors is, however, controlled by the frequency of vegetative incompatibility (vic) genes in $O$. novo-ulmi populations, which prevents hyphal fusion, and by sexual reproduction, as ascospores are free from d-factors (Brasier 2000b). Therefore the possibility of using mycoviruses to control O. novo-ulmi diminishes as genetic diversity of the pathogen increases. One feasible application of d-factors could be their release in locations where O. novo-ulmi shows low vic diversity. This situation usually occurs when $O$. novo-ulmi initially spreads in epidemic fronts, where a single genotype predominates in the population. In Europe, however, O. novo-ulmi populations diversified into numerous vic types when survival of the predominant genotypes was threatened by the spread of d-factors (Brasier et al. 2004). In some areas of North America and New Zealand the feasibility of biological control with mycoviruses is higher because the vic diversity of the pathogen is low (Hintz et al. 2013; Ganley and Bulman 2016). Implementation of the control method in these areas could consist of releasing elm bark beetles painted with d-infected fungal spores of the same vic type as a locally dominant pathogen, as suggested by Brasier (2000b). Areas where the number of vic genotypes is high will require more complex strategies to bypass the barriers for virus spread. Releasing genetically modified fungal isolates has been proposed (Brasier 2000b), but the unexpected ecological consequences of 
using modified strains should be carefully evaluated. The use of mycoviruses as biocontrol agents has already proven satisfactory in another forest pathosystem-the chestnut blight-in many areas of Europe (Griffin 2000). This strategy failed in North America, most likely due to vegetative incompatibility between blight fungus isolates which, as in the case of $O$. novo-ulmi, prevents virus spread (Kubisiak and Milgroom 2006).

In addition to d-factors, several studies have explored the possibility of enhancing tree resistance to DED using preventive inoculations with little pathogenicity for elms. These include preventive inoculation of low-virulent strains of $O$. ulmi or preventive application of a glycoprotein isolated from the DED pathogen that elicited defense mechanisms in the tree (Hubbes and Jeng 1981; Hubbes 2004). Preventive inoculations with O. ulmi, although potentially producing disease symptoms, enhanced tree resistance against subsequent infection with $O$. novo-ulmi but did not confer absolute immunity, while the success of the elicitor treatment was dependent on tree genotype and environmental conditions (Hubbes 2004). It appears that no commercial applications based on $O$. ulmi or its sub-products have been developed. Other organisms tested to enhance tree resistance included Pseudomonas bacteria (Scheffer 1983), strains of Ophiostoma piceae (Sutherland et al. 1995), Verticillium spp. (Scheffer 1990; Solla and Gil 2003) and Phaeotheca dimorphospora (Bernier et al. 1996). Overall, the effectiveness of these treatments was highly dependent on elm genotype and environmental conditions. The strain of Verticillium albo-atrum WCS850 showed good biocontrol potential and has been applied as a preventive commercial treatment (Dutch Trig ${ }^{\circledR}$ ) since 1992, providing protection against DED in urban environments (Postma and Goossen-van de Geijn 2016). As a consequence of its limited spread and survival in the tree, injections with WCS 850 must be repeated annually to be effective and therefore this method has limited relevance in large-scale forestry.

The possible role of endophytic microorganisms in the mechanisms of elm tolerance to DED is also under research. It is hypothesized that part of the microbiome inhabiting elm tissues has a role in defense against pathogens, as seen in other pathosystems (Bettucci and Alonso 1997; Gennaro et al. 2003). The phenotypic resistance shown by certain elms under field conditions may be influenced by microbiome composition. Phenotypic tolerance shown by a particular elm genotype under experimental conditions may also be influenced by a specific microbiome characteristic of the genotype (Newcombe 2011). Research on the microbiome of plants is a booming field (Hunter 2016) that will probably be taken into account in the near future in breeding forest trees against pathogens and abiotic stresses (Newcombe 2011), e.g. by promoting tree varieties prone to hosting a specific microbiome composition or engineering endophytic communities in the forest. Several works are in progress to explore the diversity and functions of elm endophytes. The diversity of xylem endophytic fungi isolated in artificial media was found to be higher in susceptible elm genotypes to DED than in tolerant genotypes, probably as a consequence of the different chemical profile of the two tree groups in xylem tissues (Martín et al. 2013). The ability of certain elm endophytes to metabolize carbon sources was comparable to that of $O$. novo-ulmi, showing an extensive niche overlap between endophytes and the pathogen and suggesting that some endophyte strains may protect elms against DED pathogen through competition for substrates (Blumenstein et al. 2015). Other works have reported that a large proportion of endophytic fungi isolated in artificial media show some degree of antagonism to DED pathogens (Webber and Hedger 1986; Martín et al. 2015b). However, this in vitro antagonism is not directly translated into stable in planta protection against DED (Martín et al. 2015b). Research is under way to evaluate the endophytic composition of resistant and tolerant clones through metabarcoding tools, permitting the exploration of the unculturable fraction of the endobiome. Using these techniques, the abundance of certain 
elm endophyte taxa seems to correlate with host tolerance to DED. Plant colonization by these endophytes reduces the expression of stress-related genes after inoculation with $O$. novo-ulmi (authors, unpublished results). As research on the biology and ecology of endophytes of forest trees advances, the relevance of the endophytic microbiome in breeding programs and biocontrol strategies is likely to increase (see Newcombe 2011 for further discussion).

\section{Is sufficient knowledge of elm ecology available to initiate restoration?}

\section{Functional host and pathogen factors to consider in elm restoration projects}

Worldwide devastation of elm stands caused by land-use change and particularly DED has made it urgent to initiate recovery through large-scale plantations. Ambitious breeding programs in Europe and North America have identified some genotypes of $U$. minor and $U$. americana expressing few symptoms of DED after repeated inoculations with aggressive fungal strains as suitable forest reproductive material for use in plantations (e.g., Martín et al. 2015a). Improved vegetative propagation and micropropagation techniques have enabled the creation of large plant stocks in a relatively short period of time. Yet compared to other forest species on the verge of local extinction that have specific recommendations on field plantation sites and methods (e.g. Castanea dentata in North America; Jacobs et al. 2013; Clark et al. 2016), for elms there is virtually no information on the most suitable microsites, planting methods, planting dates and stock characteristics. So far, recommendations on elm plantation sites have been tentative. They are based on very few field trials (Griffin et al. 2017; Knight et al. 2012, 2017; see "Testing pilot forest restoration with elms" section) and a few experiments addressing how environmental conditions affect plant ecophysiology, fungal development and elm resistance to DED.

To successfully reintroduce elms into their former sites, it is important to further investigate the influence of abiotic and biotic factors on elm ecophysiology, bark beetle behavior, fungal development and elm resistance to DED. Soil water content is important in elm-Ophiostoma interactions. Although drought stress reduces elm growth and survival, drought can increase or decrease elm resistance to Ophiostoma spp. as a result of alterations in both the plant and the pathogen (Kolb et al. 2016). The net outcome depends on the timing, intensity and duration of drought. Physiological stress on the host can increase or decrease available carbon for defense. When drought stress is mild or moderate, a greater decrease occurs in growth than in leaf photosynthetic $\mathrm{CO}_{2}$ uptake, increasing the amount of carbon substrates for use in the defense system. When drought stress is severe, a greater decrease occurs in leaf photosynthetic $\mathrm{CO}_{2}$ uptake than in plant respiration, reducing concentrations of nonstructural carbohydrates and possibly tree defense capacity (RodríguezCalcerrada et al. 2017). This is one explanation for the higher resistance of $U$. minor and $U$. americana to DED in conditions of moderate drought (Kais et al. 1967 as cited in Sutherland et al. 1997; Solla and Gil 2002b). Another explanation is the reduction of xylem vessel diameter caused by drought, which would slow down the propagation of the pathogen, as illustrated in Fig. 4. This is insufficient to advise planting elms in microsites prone to mild drought, firstly because it is recommended that plantlets from the few DED-resistant genotypes still available should attain maturity and sexually reproduce as early as possible to enhance genetic diversity before more aggressive strains of $O$. novo-ulmi appear, and secondly, trees weakened by repeated drought stress could be more attractive to bark beetles 
or other insects, further weakening trees, e.g. Xanthogaleruca luteola (Santini and Faccoli 2015). Hypoxic stress by flooding similarly reduces growth and survival, depending on the degree of flood tolerance of Ulmus species (Newsome et al. 1982; Li et al. 2015). Within the macrohabitat selected for plantations (typically floodplains and riverside areas), the distance to the water course and the extent of seasonal variation in water table depth must be taken into account. In an ongoing field trial with five resistant $U$. minor genotypes in Spain, first-year growth and survival after planting were higher and xylem water potential was less negative in plots closer to the river (unpublished results). Plantations should avoid microsites prone to long-lasting droughts and floods, although more specific recommendations will require more field studies across a range of climate regions.

Other factors that should be taken into account in re-introduction programs because of their influence on elm-Ophiostoma interaction include irradiance, competition, herbivory pressure, temperature, and phenology. Few studies have addressed the importance of irradiance to DED susceptibility. Sutherland et al. (1997) observed that, independently of air temperature and vapor pressure deficit, defoliation following $O$. novo-ulmi artificial inoculation was lower in years with higher irradiance. They reported that increased irradiance may limit upward xylem fungal spreading by reducing transpiration. Another explanation is related to the role of irradiance on the activation of defense mechanisms mediated by salicylic acid (Roden and Ingle 2009). Because elms that succumbed to DED were not always replaced by other tree species, elms are often planted in open areas with high irradiance where there is also high competition from herbaceous and shrub species and high herbivory pressure. Apart from the obvious effect of herbivores in reducing growth, a less straightforward effect of herbivory on elm performance is the induction of systemic chemical defenses potentially involved in DED resistance (Biggs 1992), which has received no attention. Concerning the influence of temperature, as prevailing air temperatures approach the optimum growth temperature of $O$. novo-ulmi $\left(20-26^{\circ} \mathrm{C}\right)$, defoliation after $O$. novoulmi inoculation increases (Sutherland et al. 1997). However, this information is difficult to implement in planting guidelines. Interestingly, Ghelardini and Santini (2009) reported that susceptibility to DED in U. minor was correlated with geographic origin and bud burst date, with southern and early flushing clones showing the least symptoms. They argued that early flushing is a mechanism of disease avoidance owing to asynchrony between host's most susceptible period and time of natural infection by DED vectors.

Many uncertainties still surround elm re-introduction projects. It is unclear how ongoing climate change will affect interaction between the few non-native resistant genotypes that will necessarily be used in some regions and bark beetle vectors (Scolytus and Hylurgopinus spp.) and endophytic fungal symbionts. Although elm field performance is little understood, successful restoration of elm stands is closer than ever to becoming a reality.

\section{Potential threats to elm restoration projects}

One of the main threats for the conservation of native genetic resources is potential hybridization with exotic species. In the case of European elms, there is particular risk in hybridization between $U$. minor and the invasive $U$. pumila, which occur in sympatry in many regions of southern Europe. Ulmus pumila grows quickly, shows good tolerance to drought and cold, and has been widely cultivated throughout southern Europe, North America and Asia. It was widely used as an ornamental tree (Cogolludo-Agustín et al. 2000), although it is considered inferior to European elms in ornamental value (according to European standards), crown density and growth. Siberian elm displays moderate to high tolerance to DED 
pathogens and was therefore widely planted to replace native elms killed by DED in some countries, including Italy (Goidanich 1936) and the United States (Zalapa et al. 2010), especially in urban environments. However, it has naturally hybridized with $U$. minor in southern Europe (Cogolludo-Agustín 2000; Brunet et al. 2013; Bertolasi et al. 2015) and U. rubra in the United States (Zalapa et al. 2009). Due to its high reproductive potential and propensity for hybridization, the Siberian elm has become an invasive species in many areas of the United States and southern Europe (Brunet et al. 2013; Cogolludo-Agustín et al. 2000). A pattern of introgression biased towards $U$. pumila was reported in Spain and the United States (Cogolludo-Agustin et al. 2000; Zalapa et al. 2009, 2010). Although hybrids were also common in Italy, the pattern of introgression was not as strongly biased towards U. pumila as in the United States (Brunet et al. 2013), possibly due to the lower susceptibility to DED of $U$. minor relative to $U$. rubra, resulting in a higher abundance of healthy $U$. minor over the landscape (Brunet et al. 2013). If no measures are taken to control this hybridization, the biased pattern of introgression towards $U$. pumila suggests that in the long term U. minor will likely become assimilated (Brunet et al. 2013). A potential advantage of introgression towards $U$. minor would be the transmission of DED resistance alleles from $U$. pumila, while introgression towards $U$. pumila could facilitate acquisition of genes from the native $U$. minor that would enable $U$. pumila to invade $U$. minor habitats, collectively increasing its ability to spread (Brunet et al. 2013, Bertolasi et al. 2015). If the aim is to restore native elm populations and their ecological roles to pre-DED status or at least approach this level, future plantations should restrict the use of U. pumila and encourage the use of native tolerant $U$. minor clones.

DED-tolerant elms selected for forest or landscape plantations could be threatened by other diseases and pests that would compromise their growth and health. Among these, elm yellow (EY) and the elm leaf beetle (ELB) are of major concern. Elm yellow is caused by a phytoplasma (parasitic phloem-restricted bacterium) that induces elm phloem necrosis. It is an aggressive disease for several elm species and hybrids and is widespread in North America and Europe (Marcone 2017). The EY pathogen, "Candidatus Phytoplasma ulmi" (Lee et al. 2004), is transmitted by leafhoppers. In elms native to North America, EY causes epinasty, chlorosis, brown discoloration of the phloem and tree death one to two years after the first foliar symptoms. In European and Asian elms, the most characteristic symptom is the formation of witches' brooms, but these trees do not show phloem discoloration and are less prone to decline (Mittempergher 2000). In North America, destructive pandemics of EY were reported last century, and in Europe EY has been described in Italy, France and central Europe (Marcone 2017, and references therein), but its impact on European elms has been much less severe. However, the frequency of EY is probably underestimated in Europe (Boudon-Padieu et al. 2004). Because native European elms show greater tolerance and lower infection rates to EY than Asian species, Mittempergher (2000) suggested elm breeders should focus on improving DED resistance in native European species. But even focusing on native elms, high intraspecific susceptibility to EY is expected to occur and therefore it is important to provide future elm populations with sufficient genetic diversity, because the use of one clone or a few known for their tolerance to DED may be threatened by high susceptibility to EY. Testing the susceptibility of each elm cultivar to O. novo-ulmi and EY would be desirable, at least when the area for restoration has a history of EY.

The ELB is a serious foliar pest in elms and can weaken tree defense. Adults and larvae feed on elm leaves, causing defoliation, reducing the photosynthetic capacity of the tree and rendering it more susceptible to other pests and diseases. ELB is native to Europe, where it is often heavily predated by the chalcidoid egg parasitoid wasp Oomyzus gallerucae 
(Büchel et al. 2016). Parasitization rates of 50-90\% of ELB eggs by O. gallerucae have been reported (Dahlsten et al. 1994; Kwong and Field 1994) and therefore this wasp acts as a natural biocontrol method against infestation. However, heavy ELB infestations are relatively frequent in urban and landscape elms. High trichome density on the foliage of elm species may be associated with reduced ELB herbivory (Bosu and Wagner 2008). Ulmus pumila and hybrids with $U$. minor are also susceptible to ELB. The ELB was introduced into the United States and Australia, where it has been responsible for heavy defoliation of elms owing to the lack of parasitoids (Büchel et al. 2016). Interestingly, it has been shown that the blend of volatile leaf compounds (terpenoids and sesquiterpenoids) of healthy trees differs qualitatively and quantitatively from that of ELB-infested plants (Wegener et al. 2001). These ELB-induced volatiles attract the egg parasitoid O. gallerucae (Meiners and Hilker 2000), reducing the number of future larvae that would further damage the plant.

Attention should also be given to the population dynamics of the DED pathogen and the potential emergence of new phenotypes able to break the resistance mechanisms of selected elm varieties. Brasier (2000a) and Brasier and Kirk (2010) demonstrated the emergence of hybrids between the subspecies of O. novo-ulmi (ssp. americana and ssp. novoulmi). The populations of these subspecies now overlap in Europe, hybridizing at high rates and giving rise to progenies just as fit for growth and pathogenesis as their parent subspecies. These events indicate the rapid evolutionary development of the pathogen, because hybrids combine phenotypic traits of the parent subspecies, most of which are of presumed adaptive significance (Brasier and Kirk 2010). This potential risk once again highlights the need to increase the genetic diversity of resistant elm genotypes as much as possible. Because resistance to DED seems to be polygenic, controlled crossings should be designed in breeding programs to combine alleles associated with resistance in the progenies. This would decrease the possibility of an $O$. novo-ulmi strain breaking the resistance of selected clones. Developing molecular markers of resistance could be very useful for this, leading to molecular-assisted selection and breeding of elms in the near future.

\section{Testing pilot forest restoration with elms}

Due to the impact of DED, few European elms have been planted in natural systems in the last 100 years. Pilot plantations with tolerant elms are needed to gain knowledge and best practices for successful establishment of elm populations. After selecting several $U$. minor clones with tolerance to $O$. novo-ulmi, the Spanish elm breeding program initiated pilot reforestation of riparian areas in central Spain. The overall objectives are to monitor acclimation of selected clones to riparian habitats presumed to be suitable for reintroduction and to gain experience and ecological knowledge for future implementation of largescale elm restoration activities. The actions are co-financed by the European Commission through the LIFE + project LIFE + ELM, (LIFE13 BIO/ES/000556) (Fig. 5).

Although restoration areas were selected on land potentially suitable for elms, plants will probably face adverse biotic and abiotic factors and therefore continuous monitoring of their survival, growth and physiological status will be essential. Due to the lack of earlier restoration attempts, it will be necessary to evaluate factors such as distance to the river, elevation, soil humidity, and incidence of pests, diseases and herbivory to form conclusions about the adaptability and survival of each elm genotype. Around 9000 U. minor trees of the selected tolerant clones (Martin et al. 2015a) are being propagated in vitro. Planting is divided over three consecutive years (2017-2019) in natural or semi-natural stands in Aranjuez, a municipality where elms historically had a significant role in the 

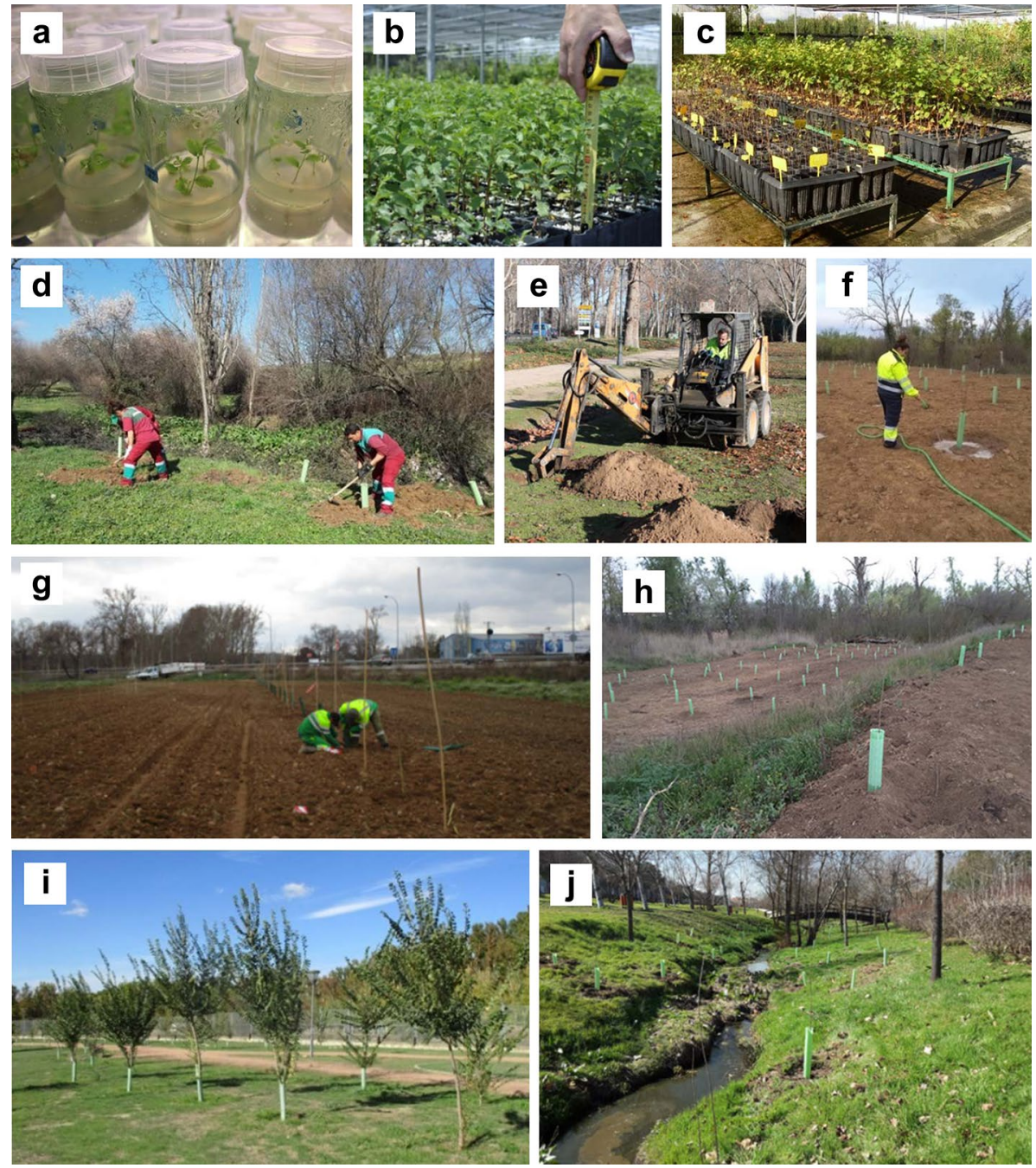

Fig. 5 Restoration activities of the LIFE + Elm project in Spain. a In vitro propagation of selected clones; b monitoring of survival and growth of saplings in the nursery; c growth of plants in seedling pots under a shading mesh during the first two seasons; d manual hole opening; e mechanized hole opening; f watering of plants after planting; $\mathbf{g}$ recovery of historic pathways in Aranjuez (Madrid) lined with rows of elms; $\mathbf{h}$ $U$. minor plantation in a riparian area in Aranjuez (elms are planted at various distances from the river and elevations to monitor the behavior of each clone); $\mathbf{i} U$. minor trees planted in a public park in Aranjuez; $\mathbf{j} U$. laevis trees planted in a semi-natural park in San Sebastián de los Reyes (Madrid)

forest landscape (Gil et al. 2003). Urban parks and roadways will also be planted with tolerant elms. In particular, degraded historic pathways will be lined with rows of elms in an attempt to recover their significant role in the cultural landscape of Aranjuez, which is included on the UNESCO World Heritage List.

Another objective of the project is to evaluate the potential use of $U$. laevis in work to restore riparian habitats. Spanish populations of this species are small and highly 
fragmented, with the concomitant risk of genetic drift (Fuentes-Utrilla et al. 2014). The limited attractiveness of this species for the elm bark beetles points to a low risk of DED damage in $U$. laevis populations, as reported in dynamic conservation activities with $U$. laevis in France (Collin and Bozzano 2015). However, intense monitoring of the evolution of the plantation will be essential to unravel the potential of this species in restoration. Around 7000 U. laevis seedlings will be planted in the municipality of San Sebastián de los Reyes (central Spain), mainly in natural areas designated as Sites of Community Importance in the Natura 2000 Network. Because this species is more water-demanding than $U$. minor ( $\mathrm{Li}$ et al. 2015), it will be planted closer to the river in an attempt to ensure the continuous influence of the water table on plantations.

The ultimate goal is for the populations of both elm species to reach sexual maturity in 7-10 years so they can contribute to gene flow and conservation of native genetic resources. Because tolerance to DED has been shown to be inheritable, progenies are likely to have similar tolerance to parent trees (Solla et al. 2015; Venturas et al. 2014). However, there is a risk of natural crossing with neighboring elms of lower tolerance, or with $U$. pumila. To mitigate these potential risks, similar actions in the future should incorporate new tolerant genotypes in surrounding areas to promote both genetic diversity and superior DED tolerance. Further breeding efforts are needed to achieve these objectives. Another key aim of LIFE +Elm is to transfer the knowledge and experience gained in the project to other players in forest restoration and the general public. A comprehensive handbook on elm management is being produced and several seminars and social activities have been organized to inform the public about the activities of the project.

\section{Regulatory and social aspects of using tolerant elms in forest restoration}

Marketing of forest reproductive materials in the European Union is governed by Council Directive 1999/105/CE. Annex I of the directive lists the forest species whose production and marketing must comply with a series of requirements. Reproductive materials included in this regulation must meet external quality standards, where applicable. The overall objective is to control the origin and genetic quality of reproductive materials used in planting to ensure the use of certified plants that are well adapted to local conditions, enabling future forests to grow healthier, be more stable and provide improved ecosystem services to society. Although Ulmus species are not included in Annex I, Article 3.2 allowed Member States to add forest species of local importance to the list. Several countries expressed a need to certify the origin and genetic quality of certain species, including Ulmus. The Spanish regulation added 24 forest species, among them $U$. glabra and $U$. minor (Iglesias 2005). Because the spread of $U$. pumila in Spain and its propensity to hybridize with $U$. minor (Cogolludo-Agustín et al. 2000) led to conservation concerns for the native species, artificial hybrids with Asian elms were not included in the regulation, to encourage the use of native elms in forestry. The genetic quality of plant material must be guaranteed by experimental protocols, and in the case of elms it is mandatory to test the tolerance of selected clones to $O$. novo-ulmi in experimental trials before they are certified (Martin et al. 2015a).

Interest in elm recovery appears to be growing in today's society. Stakeholders concerned about elm restoration include environmental groups, public administrations, research centers, private owners, plant producers and the general public (Knight et al. 2017). The participation of such diverse sectors could provide a range of perspectives about 
how elm conservation and restoration should be implemented in the future. To advance in elm restoration and overcome difficulties or disagreements among the sectors involved, scientific knowledge about elms and DED should be passed on to society. Many councils in towns and cities where elms once provided shade and embellishment are interested in recovering this species as they become aware of the availability of tolerant elm clones. Native species and hybrids with outstanding ornamental qualities are being planted in towns and cities in various European locations and are generally well accepted (e.g. Hiemstra 2013). In forestry the demand for elms remains low, probably conditioned by mistrust about the future behavior of clones selected for DED tolerance. To gain confidence in the forest sector, pilot forest restorations with tolerant elms are needed, together with more breeding efforts to enable selection of new tolerant or resistant native clones. The possibility of using tolerant elms for other forest purposes should also be explored, for instance for wood production (Santini et al. 2004) or phytoremediation (Saba et al. 2015). The potential of Siberian elm has been tested in assays for biomass production (Pérez-García 2016) and European elms could offer similar or even superior qualities for this purpose.

Future efforts should focus on selecting native elms, because backcross breeding of plants to exotic species may prove less publicly accepted in forest restoration (Jacobs 2007). Acceptance of genetically modified elms in the future is also uncertain, although cisgenic approaches, with a concept closer to traditional breeding, could offer new options for elm restoration. Molecular information gathered in the next few years will be decisive to boost elm breeding and lay strong foundations for future elm restoration actions. In any event, continuous monitoring of reintroduced elms to evaluate their adaptation and regeneration appears to be mandatory in setting realistic species restoration objectives for the future.

\section{Conclusions}

Restoring elm populations remains both a major challenge and a cultural and scientific responsibility. The availability of DED-resistant plant material to accomplish large-scale restoration activities is probably insufficient, especially if the aim is to use native material only. However, small-scale restoration activities are feasible and recommended, as is the use of tolerant elms in urban forestry. The strategy for fighting DED still relies on traditional breeding, but recent scientific advances, mainly on the molecular side, will open up new prospects for developing molecular-assisted selection and breeding techniques for tolerant elms in the next few years, reducing the time periods required. Producing genetically engineered elms has proven feasible, although social concerns are likely to prevent largescale implementation. It is expected that new tolerant cultivars with native background will be released onto the market, increasing the possibilities for sustained elm reintroduction in the long term. Meanwhile, there is a clear need for further research on elm ecology under a changing climate, evolution of DED pathogen populations, biocontrol methods and potential technological uses of tolerant elms. It is imperative to involve all stakeholders in defining, implementing and monitoring elm restoration objectives and to pass on scientific and technical advances to society.

Acknowledgements The authors would like to acknowledge the large number of people who have participated in research, breeding, and restoration of elms. The constructive comments by two anonymous reviewers are gratefully acknowledged. The research and restoration works in Spain described in this work are funded by the projects AGL2015-66925-R (MINECO/FEDER) and LIFE13 BIO/ES/000556 LIFE Elm, 
respectively. The support of the Spanish Environmental Administration (MAPAMA) to elm breeding and research is gratefully acknowledged.

\section{Compliance with ethical standards}

Conflicts of interest Authors declare that they have no conflict of interest.

Human and animals rights This work did not involve human participants or animals.

Open Access This article is distributed under the terms of the Creative Commons Attribution 4.0 International License (http://creativecommons.org/licenses/by/4.0/), which permits unrestricted use, distribution, and reproduction in any medium, provided you give appropriate credit to the original author(s) and the source, provide a link to the Creative Commons license, and indicate if changes were made.

\section{References}

Anderbrant O, Yuvaraj JK, Martin JA, Gil L, Witzell J (2017) Feeding by bark beetles to test for differently susceptible elm varieties. J Appl Entomol 141(5):417-420

Aoun M, Rioux D, Simard M, Bernier L (2009) Fungal colonization and host defense reactions in Ulmus americana callus cultures inoculated with Ophiostoma novo-ulmi. Phytopathology 99:642-650

Aoun M, Jacobi V, Boyle B, Bernier L (2010) Identification and monitoring of Ulmus americana transcripts during in vitro interactions with the Dutch elm disease pathogen Ophiostoma novo-ulmi. Physiol Mol Plant Pathol 74:254-266

Armstrong JV (1992) Taxonomy of British elms. PhD Thesis, University of Cambridge

Armstrong JV, Sell PD (1996) A revision of British elms (Ulmus L., Ulmaceae): the historical background. Bot J Linn Soc 120:39-50

Aziz AN, Sauvé RJ, Zhou S, Meng X (2003) Microprojectile-mediated genetic transformation and regeneration of Chinese elm. Can J Plant Sci 83:587-591

Bates MR, Buck KW, Brasier CM (1993) Molecular relationships between Ophiostoma ulmi and the NAN and EAN races of $O$. novo-ulmi determined by restriction fragment length polymorphisms of nuclear DNA. Mycol Res 97:449-455

Beier GL, Held BW, Giblin CP, Cavender-Bares J, Blanchette RA (2017) American elm cultivars: variation in compartmentalization of infection by Ophiostoma novo-ulmi and its effects on hydraulic conductivity. For Pathol. https://doi.org/10.1111/efp.12369

Benito J (1936) La grafiosis del olmo y la demostración de su existencia en España. Instituto Forestal de Investigaciones y Experiencias, Madrid

Bernier L, Jeng RS, Hubbes M (1983) Differentiation of aggressive and non-aggressive strains of Ceratocystis ulmi by polyacrylamide gel electrophoresis of intramycelial enzymes. Mycotaxon 17:456-472

Bernier L, Yang D, Ouellette GB, Dessureault M (1996) Assessment of Phaeotheca dimorphospora for biological control of the Dutch elm disease pathogens, Ophiostoma ulmi and O. novo-ulmi. Plant Pathol 45:609-617

Bernier L, Aoun M, Bouvet GF, Comeau A, Dufour J, Naruzawa ES, Nigg M, Plourde KV (2015) Genomics of the Dutch elm disease pathosystem: are we there yet? iForest 8:149-157

Bertolasi B, Leonarduzzi C, Piotti A, Leonardi S, Zago L, Gui L, Gorian F, Vanetti I, Binelli G (2015) A last stand in the Po valley: genetic structure and gene flow patterns in Ulmus minor and U. pumila. Ann Bot-London 115:683-692

Bettucci L, Alonso R (1997) A comparative study of fungal populations in healthy and symptomatic twigs of Eucalyptus grandis in Uruguay. Mycol Res 101:1060-1064

Biggs AR (1992) Responses of angiosperm bark tissues to fungi causing cankers and canker rots. In: Blanchette RA, Biggs AR (eds) Defense mechanisms of woody plants against fungi. Springer series in wood science. Springer, Berlin, pp 41-61

Blumenstein K, Albrectsen BR, Martín JA, Hultberg M, Sieber TN, Helander M, Witzell J (2015) Nutritional niche overlap potentiates the use of endophytes in biocontrol of a tree disease. Biocontrol 60:655-667

Bolyard MG, Hajela RK, Sticklen MB (1991) Microprojectile and Agrobacterium-mediated transformation of pioneer elm. J Arboric 17:34-37 
Bosu PP, Wagner MR (2008) Anatomical and nutritional factors associated with susceptibility of elms (Ulmus spp.) to the Elm Leaf Beetle (Coleoptera: chrysomelidae). J Econom Entomol 101:944-954

Boudon-Padieu E, Larrue J, Clair D, Hourdel J, Jeanneau A, Sforza R, Collin E (2004) Detection and prophylaxis of elm yellows phytoplasma in France. Invest Agrar: Sist Recur For 13:71-80

Bouvet GF, Jacobi V, Bernier L (2007) Characterization of three DNA transposons in the Dutch elm disease fungi and evidence of repeat-induced point (RIP) mutations. Fungal Genet Biol 44:430-443

Bowden CG, Hintz WE, Jeng RS, Hubbes M, Horgen PA (1994) Isolation and characterization of the cerato-ulmin gene of the Dutch elm disease pathogen, Ophiostoma ulmi. Curr Genet 25:323-329

Bowden CG, Smalley E, Guries RP, Hubbes M, Temple B, Horgen PA (1996) Lack of association between cerato-ulmin production and virulence in Ophiostoma novo-ulmi. Mol Plant-Microbe In 9:556-564

Brasier CM (1986) The d-factor in Ceratocystis ulmi - its biological characteristics and implications for Dutch elm disease. In: Buck KW (ed) Fungal virology. CRC Press, Florida, pp 177-208

Brasier CM (1996) New horizons in Dutch elm disease control. Report on Forest Research 1996. HMSO, London, pp 20-28

Brasier CM (2000a) Intercontinental spread and continuing evolution of the Dutch elm disease pathogens. In: Dunn CP (ed) The elms: breeding, conservation and disease management. Kluwer Academic Publishers, Norwell, MA, pp 61-72

Brasier CM (2000b) Viruses as biological control agents of the Dutch elm disease fungus Ophiostoma novoulmi. In: Dunn CP (ed) The elms, breeding, conservation, and disease management. Kluwer Academic Publishers, Norwell, MA, pp 201-212

Brasier CM, Kirk SA (2010) Rapid emergence of hybrids between the two subspecies of Ophiostoma novoulmi with a high level of pathogenic fitness. Plant Pathol 59:186-199

Brasier CM, Kirk SA, Pipe N, Buck KW (1998) Rare hybrids in natural populations of the Dutch elm disease pathogens Ophiostoma ulmi and O. novo-ulmi. Mycol Res 102:45-57

Brasier CM, Buck K, Paoletti M, Crawford L, Kirk S (2004) Molecular analysis of evolutionary changes in populations of Ophiostoma novo-ulmi. Invest Agrar: Sist Recur For 13:93-103

Bräutigam A, Gowik U (2010) What can next generation sequencing do for you? Next generation sequencing as a valuable tool in plant research. Plant Biol 12:831-841

Brunet J, Zalapa JE, Pecori F, Santini A (2013) Hybridization and introgression between the exotic Siberian elm, Ulmus pumila, and the native Field elm, U. minor, in Italy. Biol Invasions 15:2717-2730

Brunet J, Zalapa J, Guries R (2016) Conservation of genetic diversity in slippery elm (Ulmus rubra) in Wisconsin despite the devastating impact of Dutch elm disease. Conserv Genet 17:1001-1010

Büchel K, McDowell E, Nelson W, Descour A, Gershenzon J, Hilker M, Soderlund C, Gang DR, Fenning T, Meiners T (2012) An elm EST database for identifying leaf beetle egg-induced defense genes. BMC Genom 13:242

Büchel K, Fenning T, Gershenzon J, Hilker M, Meiners T (2016) Elm defence against herbivores and pathogens: morphological, chemical and molecular regulation aspects. Phytochem Rev 15:961-983

Buisman CJ (1928) The cause of the elm disease. Translated in: Holmes FW, Heybroek HM (1990) Dutch elm disease-the early papers. APS Press, St. Paul, pp 105-110

Buiteveld J, Van Der Werf B, Hiemstra JA (2015) Comparison of commercial elm cultivars and promising unreleased Dutch clones for resistance to Ophiostoma novo-ulmi. iForest 8:158-164

Buiteveld J, Vanden Broeck A, Cox K, Collin E (2016) Human impact on the genetic diversity of Dutch field elm (Ulmus minor) populations in the Netherlands: implications for conservation. Plant Ecol Evol 149:165-176

Clark SL, Schlarbaum SE, Saxton AM, Hebard FV (2016) Establishment of American chestnuts (Castanea dentata) bred for blight (Cryphonectria parasitica) resistance: influence of breeding and nursery grading. New Forest 47:243-270

Cogolludo-Agustin MA, Agundez D, Gil L (2000) Identification of native and hybrid elms in Spain using isozyme gene markers. Heredity 85:157-166

Coleman M, A'Hara SW, Tomlinson PR, Davey PJ (2016) Elm clone identification and the conundrum of the slow spread of Dutch elm disease on the Isle of man. New J Bot 6:79-89

Collada C, Fuentes-Utrilla P, Gil L, Cervera MT (2004) Characterization of microsatellite loci in Ulmus minor miller and cross-amplification in U. glabra Hudson and U. laevis Pall. Mol Ecol Resour 4:731-732

Collin E, Bozzano M (2015) Implementing the dynamic conservation of elm genetic resources in Europe: case studies and perspectives. iForest 8:143-148

Collin E, Bilger I, Eriksson G, Turok J (2000) The conservation of elm genetic resources in Europe. In: Dunn CP (ed) The elms: breeding, conservation and disease management. Kluwer Academic, Dordrecht, pp 281-293 
Collin E, Rusanen M, Ackzell L, Bohnens J, De Aguiar A, Diamandis S, Franke A, Gil L, Harvengt L, Hollingsworth P, Jenkins G, Meier-Dinkel A, Mittempergher L, Musch B, Nagy L, Pâques M, Pinon J, Piou D, Rotach P, Santini A, Broeck AV, Wolf AH (2004) Methods and progress in the conservation of elm genetic resources in Europe. Invest Agrar: Sist Recur For 13:261-272

Comeau AM, Dufour J, Bouvet GF, Jacobi V, Nigg M, Henrissat B, Laroche J, Levesque RC, Bernier L (2015) Functional annotation of the Ophiostoma novo-ulmi genome: insights into the phytopathogenicity of the fungal agent of Dutch elm disease. Genome Biol Evol 7:410-430

Corredoira E, San José MC, Vieitez AM, Allona I, Aragoncillo C, Ballester A (2016) Agrobacterium-mediated transformation of European chestnut somatic embryos with a Castanea sativa (Mill.) endochitinase gene. New Forest 47:669-684

Dahlsten DL, Rowney DL, Tait SM (1994) Development of integrated pest management programs in urban forests: the elm leaf beetle (Xanthogaleruca luteola (Müller)) in California, USA. For Ecol Manag 65:31-44

Dorion N, Hassairi A, Guyon P, Godin B, Bigot C (1995) In vitro budding ability of woody internode and Agrobacterium susceptibility as prerequisites for elm genetic transformation. J Plant Physiol 146:699-703

Duchesne LC (1993) Mechanisms of resistance: can they help save susceptible elms? In: Sticklen MB, Sherald JL (eds) Dutch elm disease research—cellular and molecular approaches. Springer, New York, pp 239-254

Et-Touil A, Brasier CM, Bernier L (1999) Localization of a pathogenicity gene in Ophiostoma novo-ulmi and evidence that it may be introgressed from O. ulmi. Mol Plant Microbe In 12:6-15

Fenning TM, Tymens SS, Gartland JS, Brasier CM, Gartland KMA (1996) Transformation and regeneration of English elm using wild-type Agrobacterium tumefaciens. Plant Sci 116:37-46

Fenning TM, Gartland JS, Brasier CM, Tymens SS, Gartland KMA (1997) Strategies for genetic manipulation of elm trees. In: Ahuja MR (ed) Somatic cell genetics and molecular genetics of trees. For Sci vol 49, pp 105-112

Forgetta V, Leveque G, Dias J, Grove D, Lyons R Jr, Genik S, Wright C, Singh S, Peterson N, Zianni M, Kieleczawa J, Hintz W, Jacobi V, Bernier L, Levesque R, Dewar K (2013) Comparison of multiple genome sequencing centers and analysis of the Dutch elm disease fungus genome using the Roche/454 GS-FLX Titanium System. J Biomol Tech 24:39-49

Foster ES, Heffner E (translators) (1954) Lucius junius moderatus columella: on agriculture II. Harvard University Press, Cambridge, reprinted 1977

Fuentes-Utrilla P, Venturas M, Hollingsworth PM, Squirrell J, Collada C, Stone GN, Gil L (2014) Extending glacial refugia for a European tree: genetic markers show that Iberian populations of white elm are native relicts and not introductions. Heredity 112:105-113

Ganley RJ, Bulman LS (2016) Dutch elm disease in New Zealand: impacts from eradication and management programmes. Plant Pathol 65:1047-1055

Gartland JS, McHugh AT, Brasier CM, Irvine RJ, Fenning TM, Gartland KMA (2000) Regeneration of phenotypically normal English elm (Ulmus procera) plantlets following transformation with an Agrobacterium tumefaciens binary vector. Tree Physiol 20:901-907

Gartland JS, Brasier CM, Fenning TM, Birch R, Gartland KMA (2001) Ri-plasmid mediated transformation and regeneration of Ulmus procera (English elm). Plant Growth Regul 33:123-129

Gartland KMA, McHugh AT, Crow RM, Garg A, Gartland JS (2005) 2004 SIVB congress symposium proceeding: biotechnological progress in dealing with Dutch elm disease. In Vitro Cell Dev-Pl 41:364-367

Gennaro M, Gonthier P, Nicolotti G (2003) Fungal endophytic communities in healthy and declining Quercus robur L. and Q. cerris L. trees in northern Italy. J Phytopathol 151:529-534

Ghelardini L, Santini A (2009) Avoidance by early flushing: a new perspective on Dutch elm disease research. iForest 2:143-153

Gil L, López R, García-Nieto ME (2003) Historia de los olmos en la Península Ibérica. In: Gil L, Solla A, Iglesias S (eds) Los olmos ibéricos: conservación y mejora frente a la grafiosis. Organismo Autónomo Parques Nacionales, pp 69-114

Gil L, Fuentes-Utrilla P, Soto A, Cervera MT, Collada C (2004) English elm (Ulmus procera) is a 2000-year-old Roman clone. Nature 431:1035

Goidanich G (1936) La moria dell'olmo (Graphium ulmi). Ramo Editoriale Degli Agricoltori, Roma

Griffin GJ (2000) Blight control and restoration of the American chestnut. J For 98:22-27

Griffin JJ, Jacobi WR, McPherson G et al (2017) Ten-year performance of the United States national elm trial. Arboric Urban For 43:107-120

Gross A, Holdenrieder O, Pautasso M, Queloz V, Siebe TN (2014) Hymenoscyphus pseudoalbidus, the causal agent of European ash dieback. Mol Plant Pathol 15:5-21 
Häggman H, Sutela S, Fladung M (2016) Genetic engineering contribution to forest tree breeding efforts. In: Vettori C, Gallardo F, Häggman H, Kazana V, Migliacci F, Pilate G, Fladung M (eds) Biosafety of forest transgenic trees. Springer, Berlin, pp 11-29

Han K, Dharmawardhana P, Arias R, Ma C, Busov V, Strauss S (2010) Gibberellin associated cisgenes modify growth, stature and wood properties in Populus. Plant Biotechnol J 9:162-178

Heybroek HM (1993a) Why bother about the elm? In: Sticklen MB, Sherald JL (eds) Dutch elm disease research: cellular and molecular approaches. Springer, Berlin, pp 1-8

Heybroek HM (1993b) The Dutch elm breeding program. In: Sticklen MB, Sherald J (eds) Dutch elm disease research: cellular and molecular approaches. Springer, New York, pp 16-25

Heybroek HM (2015) The elm, tree of milk and wine. iForest 8:181-186

Hiemstra J (2013) Come-back of the elm as street tree in the Netherlands. Presentation at 3rd international elm conference florence (Italy) 9-11 October 2013. Book of Abstracts: 8

Hintz WE, Jeng RS, Hubbes M, Horgen PA (1991) Identification of three populations of Ophiostoma ulmi (aggressive subgroup) by mitochondrial DNA restriction-site mapping and nuclear DNA fingerprinting. Exp Mycol 15:316-325

Hintz WE, Carneiro JS, Kassatenko I, Varga A, James D (2013) Two novel mitoviruses from a Canadian isolate of the Dutch elm pathogen Ophiostoma novo-ulmi (93-1224). Virol J 10:252

Hoegger PJ, Binz T, Heiniger U (1996) Detection of genetic variation between Ophiostoma ulmi and the NAN and EAN races of $O$. novo-ulmi in Switzerland using RAPD markers. Eur J For Pathol 26:57-68

Holgado-Redondo A (1988) De los trabajos del campo, de Lucio Junio Moderato Columela. Siglo XXI de España y MAPA, Madrid

Hollingsworth PM, Hollingsworth ML, Coleman M (2000) The European elms: Molecular markers, population genetics, and biosystematics. In: Dunn CP (ed) The elms: breeding, conservation and disease management. Kluwer Academic Publishers, Norwell, MA, pp 3-20

Hooper WD, Ash HR (1934) Cato and Varro. De re rustica. Loeb Classical Library, London

Hort AF (1916) Teophrastus. Enquiry into plants. William Heineman-Hardvard University Press, London

Hou H, Atlihan N, Lu Z-X (2014) New biotechnology enhances the application of cisgenesis in plant breeding. Front Plant Sci 5:389

Hubbes M (2004) Induced resistance for the control of Dutch elm disease. Invest Agrar: Sist Recur For 13:185-196

Hubbes M, Jeng RS (1981) Aggressiveness of Ceratocystis ulmi strains and induction of resistance in Ulmus americana. Eur J For Pathol 11:257-264

Hunter P (2016) Plant microbiomes and sustainable agriculture. EMBO Rep 17:1696-1699

Iglesias S (2005) Normativa de comercialización de material forestal de reproducción. In: Alía A, Alba N, Agúndez D, Iglesias S (eds) Manual para la Comercialización y Producción de Semillas y Plantas Forestales, Materiales de Base y Reproducción. Organismo Autónomo Parques Nacionales, Ministerio de Medio Ambiente, Madrid, pp 39-58

Jacobs DF (2007) Toward development of silvical strategies for forest restoration of American chestnut (Castanea dentata) using blight-resistant hybrids. Biol Conserv 137:497-506

Jacobs DF, Dalgleish HJ, Nelson CD (2013) A conceptual framework for restoration of threatened plants: the effective model of American chestnut (Castanea dentata) reintroduction. New Phytol 197:378-393

Jeng RS, Hubbes M (1983) Identification of aggressive and non-aggressive strains of Ceratocystis ulmi by polyacrylamide gel electrophoresis of intramycelial proteins. Mycotaxon 17:445-455

Jeng RS, Duchesne LC, Sabourin M, Hubbes M (1991) Mitochondria1 DNAs restriction length polymorphisms of aggressive and non-aggressive isolates of Ophiostoma ulmi. Mycol Res 95:537-542

Khoshraftar S, Hung S, Khan S, Gong Y, Tyagi V, Parkinson J, Sain M, Moses AM, Christendat D (2013) Sequencing and annotation of the Ophiostoma ulmi genome. BMC Genom 14:162-172

Knight KS, Slavicek JM, Kappler R, Pisarczyk E, Wiggin B, Menard K (2012) Using Dutch elm disease-tolerant elm to restore floodplains impacted by emerald ash borer. In: Sniezko RA et al (ed) Proceedings of the 4th international workshop on the genetics of host-parasite interactions in forestry: disease and insect resistance in forest trees. 2011 July 31-August 5, Eugene, OR. Gen. Tech. Rep. PSW-GTR-240. Albany, CA: U.S. Department of Agriculture, Forest Service, Pacific Southwest Research Station, pp 317-323

Knight KS, Haugen LM, Pinchot CC, Schaberg PG, Slavicek JM (2017). American elm (Ulmus americana) in restoration plantings: a review. In: Proceedings of the American elm restoration workshop 2016, USDA General Technical Report NRS-P-174, pp 133-140 
Kolb TE, Fettig CJ, Ayres MP, Bentz BJ, Hicke JA, Mathiasen R, Stewart JE, Weed AS (2016) Observed and anticipated impacts of drought on forest insects and diseases in the United States. For Ecol Manag 380:321-334

Kubisiak TL, Milgroom MG (2006) Markers linked to vegetative incompatibility(vic) genes and a region of high heterogeneity and reduced recombination near the mating type locus (mat) in Cryphonectria parasitica. Fungal Genet Biol 43:453-463

Kwong RM, Field RP (1994) Elm leaf beetle history and distribution in southern Victoria. Plant Protect Quart 9:43-47

Ledford H (2015) CRISPR, the disruptor. Nature 522:20-24

Lee IM, Martini M, Marcone C, Zhu SF (2004) Classification of phytoplasma strains in the elm yellows group (16SrV) and proposal of 'Candidatus Phytoplasma ulmi' for the phytoplasma associated with elm yellows. Int J Syst Evol Micr 54:337-347

Li M, López R, Venturas M, Pita P, Gordaliza GG, Gil L, Rodríguez-Calcerrada J (2015) Greater resistance to flooding of seedlings of Ulmus laevis than Ulmus minor is related to the maintenance of a more positive carbon balance. Trees 29:835-848

Li M, López R, Venturas M, Martín JA, Domínguez J, Gordaliza GG, Gil L, Rodríguez-Calcerrada J (2016) Physiological and biochemical differences among Ulmus minor genotypes showing a gradient of resistance to Dutch elm disease. For Pathol 46:215-228

Mackenthun GL (2000) Native Elms of Saxony, Germany. In: Dunn CP (ed) The elms: breeding, conservation, and disease management. Kluwer Academic Publishers, Boston, pp 305-314

Mackenthun GL (2004) The role of Ulmus laevis in German floodplain landscapes. Invest Agrar: Sist Recur For 13:55-63

Mackenthun GL (2013) Elm Losses and their Causes over a 20 Year period-A long-term Study of Ulmus in Saxony, Germany. In: 3rd international elm conference, Florence (Italy) 9-11 October 2013. Book of abstracts, CNR-IPP Institute of Plant Protection

Marcone C (2017) Elm yellows: a phytoplasma disease of concern in forest and landscape ecosystems. Forest Pathol 47:e12324

Marcotrigiano M (2017) Elms revisited. Arboric Urban For 43:217-241

Martín JA, Solla A, Coimbra MA, Gil L (2008) Metabolic fingerprinting allows discrimination between Ulmus pumila and $U$. minor, and between $U$. minor clones of different susceptibility to Dutch elm disease. For Pathol 38:244-256

Martín JA, Solla A, Esteban LG, De Palacios P, Gil L (2009) Bordered pit and ray morphology involvement in elm resistance to Ophiostoma novo-ulmi. Can J For Res 39:420-429

Martín JA, Solla A, Gil L, García-Vallejo MC (2010) Phenological and histochemical changes of Ulmus minor due to root absorption of phenol: implications for resistance to DED. Environ Exp Bot 69:175-182

Martín JA, Witzell J, Blumenstein K, Rozpedowska E, Helander M, Sieber T, Gil L (2013) Resistance to Dutch elm disease reduces presence of xylem endophytic fungi in elms (Ulmus spp.). PLoS ONE 8:e56987

Martín JA, Solla A, Venturas M, Collada C, Domínguez J, Miranda E, Fuentes P, Burón M, Iglesias S, Gil L (2015a) Seven Ulmus minor clones tolerant to Ophiostoma novo-ulmi registered as forest reproductive material in Spain. iForest 8:172-180

Martín JA, Macaya-Sanz D, Witzell J, Blumenstein K, Gil L (2015b) Strong in vitro antagonism by elm xylem endophytes is not accompanied by temporally stable in planta protection against a vascular pathogen under field conditions. Eur J Plant Pathol 60:655-667

Masuya H, Brasier C, Ichihara Y, Kubono T, Kanzaki N (2010) First report of the Dutch elm disease pathogens Ophiostoma ulmi and O. novo-ulmi in Japan. Plant Pathol 59:805

Mauch-Mani B, Slusarenko AJ (1996) Production of salicylic acid precursors is a major function of phenylalanine ammonia-lyase in the resistance of Arabidopsis to Peronospora parasitica. Plant Cell 8:203-212

McNabb HS Jr, Heybroek HM, MacDonald WL (1970) Anatomical factors in resistance to Dutch elm disease. Neth J Plant Pathol 76:196-204

Meiners T, Hilker M (2000) Induction of plant synomones by oviposition of a phytophagous insect. J Chem Ecol 26:221-232

Melville R (1975) Ulmus. In: Stace CA (ed) Hybridization and the flora of the British Isles. Academic Press, London, pp 292-299

Mittempergher L (2000) Elm yellows in Europe. In: Dunn CP (ed) The elms: breeding, conservation, and disease management. Kluwer Academic Publisher, Boston, pp 103-119

Mittempergher L, La Porta N (1991) Hybridization studies in the Eurasian species of elm (Ulmus spp.). Silvae Genet 40:237-243 
Mittempergher L, Santini A (2004) The history of elm breeding. Invest Agrar: Sist Recur For 13:161-177

Morris H, Brodersen C, Schwarze FWMR, Jansen S (2016) The parenchyma of secondary xylem and its critical role in tree defense against fungal decay in relation to the CODIT model. Front Plant Sci $7: 1665$

Moure-Casas A (Trans.) (1990) Tratado de agricultura: Medicina veterinaria. Poema de los injertos/Paladio; traducción, introducción y notas de Ana Moure Casas. Editorial Gredos, Madrid

Nasmith C, Jeng R, Hubbes M (2008a) Targeted gene analysis in Ulmus americana and U. pumila tissues. For Pathol 38:90-103

Nasmith C, Jeng R, Hubbes M (2008b) A comparison of in vivo targeted gene expression during fungal colonization of DED-susceptible Ulmus americana. For Pathol 38:104-112

Newbanks D, Bosch A, Zimmermann MH (1983) Evidence for xylem dysfunction by embolization in Dutch elm disease. Phytopathology 73:1060-1063

Newcombe G (2011) Endophytes in forest management: four challenges. In: Pirttilä AM, Frank AC (eds) Endophytes of forest trees: biology and applications, forestry sciences 80. Springer, Berlin, pp 251-262

Newhouse AE, Schrodt F, Liang H, Maynard CA, Powell WA (2007) Transgenic American elm shows reduced Dutch elm disease symptoms and normal mycorrhizal colonization. Plant Cell Rep 26:977-987

Newsome RD, Kozlowski TT, Tang ZC (1982) Responses of Ulmus americana seedlings to flooding of soil. Can J Bot 60:1688-1695

Nielsen LR, Kjær ED (2010a) Gene flow and mating patterns in individuals of wych elm (Ulmus glabra) in forest and open land after the influence of Dutch elm disease. Conserv Genet 11:257-268

Nielsen LR, Kjær ED (2010b) Fine-scale gene flow and genetic structure in a relic Ulmus laevis population at its northern range. Tree Genet Genomes 6:643-649

Nigg M, Bernier L (2016) From yeast to hypha: defining transcriptomic signatures of the morphological switch in the dimorphic fungal pathogen Ophiostoma novo-ulmi. BMC Genom 17:920

Nigg M, Laroche J, Landry CR, Bernier L (2015) RNAseq analysis highlights specific transcriptome signatures of yeast and mycelial growth phases in the Dutch elm disease fungus Ophiostoma novo-ulmi. G3-Genes Genom Genet 5:2487-2495

O'Callaghan DP, Gallager EM, Lanier GN (1980) Field evaluation of pheromone-baited trap trees to control elm bark beetle vectors of Dutch elm disease. Environ Entomol 9:181-185

Oheimb G, Brunet J (2007) Dalby Söderskog revisited: long-term vegetation changes in a south Swedish deciduous forest. Acta Oecol 31:229-242

Oliveira H, Sousa A, Alves A, Nogueira AJA, Santos C (2012) Inoculation with Ophiostoma novo-ulmi subsp. americana affects photosynthesis, nutrition and oxidative stress in in vitro Ulmus minor plants. Env Exp Bot 77:146-155

Ouellette GB, Rioux D (1992) Anatomical and physiological aspects of resistance to Dutch elm disease. In: Blanchette RA, Biggs AR (eds) Defense mechanisms of woody plants against fungi. Springer series in wood science. Springer, Berlin, pp 257-307

Pajares JA, Martínez de Azagra A (1990) Métodos y estrategias en el control de la grafiosis. In: Gil L (ed) Los olmos y la grafiosis en España. ICONA, Colección Técnica, pp 215-246

Pajares JA, García S, Díez JJ, Martín D, García-Vallejo MC (2004) Feeding responses by Scolytus scolytus to twig bark extracts from elms. Invest Agrar: Sist Recur For 13:217-225

Parker GR, Leopold DJ (1983) Replacement of Ulmus americana L in a mature east-central Indiana woods. B Torrey Bot Club 110:482-488

Perdiguero P, Venturas M, Cervera MT, Gil L, Collada C (2015) Massive sequencing of Ulmus minor's transcriptome provides new molecular tools for a genus under the constant threat of Dutch elm disease. Front Plant Sci 6:541

Perdiguero P, Sobrino-Plata J, Venturas M, Martín JA, Gil L, Collada C (2018) Gene expression tradeoffs between defence and growth in English elm induced by Ophiostoma novo-ulmi. Plant Cell Environ 41:198-214

Perez-Garcia I (2016) Evaluación de Ulmus pumila L. y Populus spp. como cultivo energético en corta rotación. PhD thesis, Universidad Politécnica de Madrid

Pérez-Jiménez A, Martínez Díez A (Trans.) (1978) Hesíodo, obras y fragmentos. Editorial Gredos, Madrid

Peterken G, Mountford EP (1998) Long-term change in an unmanaged population of wych elm subjected to Dutch elm disease. J Ecol 86:205-218

Pieterse CM, Van der Does D, Zamioudis C, Leon-Reyes A, Van Wees SC (2012) Hormonal modulation of plant immunity. Annu Rev Cell Dev Bi 28:489-521

Pita P, Rodríguez-Calcerrada J, Medel D, Gil L (2018) Further insights into the components of resistance to Ophiostoma novo-ulmi in Ulmus minor: hydraulic conductance, stomatal sensitivity and bark dehydration. Tree Physiol 38:252-262 
Postma J, Goossen-van de Geijn H (2016) Twenty-four years of Dutch Trig application to control Dutch elm disese. Biocontrol 16:305-312

Powell WA, Catranis CM, Maynard CA (2000) Design of selfprocessing antimicrobial peptides for plant protection. Lett Appl Microbiol 31:163-168

Rhee SY, Mutwil M (2014) Towards revealing the functions of all genes in plants. Trends Plant Sci 19:212-221

Richens RH (1983) Elm. Cambridge University Press, Cambridge

Roden LC, Ingle RA (2009) Lights, rhythms, infection: the role of light and the circadian clock in determining the outcome of plant-pathogen interactions. Plant Cell 21:2546-2552

Rodríguez-Calcerrada J, Li M, López R, Cano FJ, Oleksyn J, Atkin OK, Pita P, Aranda I, Gil L (2017) Drought-induced shoot dieback starts with massive root xylem embolism and variable depletion of non-structural carbohydrates in seedlings of two tree species. New Phytol 213:597-610

Ryals JA, Neuenschwander UH, Willits MG, Molina A, Steiner HY, Hunt MD (1996) Systemic acquired resistance. Plant Cell 8:1809-1819

Saba G, Parizanganeh AH, Zamani A, Saba J (2015) Phytoremediation of heavy metals contaminated environments: screening for native accumulator plants in Zanjan-Iran. Int J Environ Res 9:309-316

Santini A, Faccoli M (2015) Dutch elm disease and elm bark beetles: a century of association. iForest 8:126-134

Santini A, Fagnani A, Ferrini F, Mittempergher L, Brunetti M, Crivellaro A, Macchioni N (2004) Elm breeding for DED resistance, the Italian clones and their wood properties. Invest Agrar: Sist Recur For 13:179-184

Santini A, Montaghi A, Vendramin GG, Capretti P (2005) Analysis of the Italian Dutch elm disease fungal population. J Phytopathol 153:73-79

Santini A, Pecori F, Ghelardini L (2012) The Italian elm breeding program for Dutch elm disease resistance. In: Sniezko RA et al (ed) Proceedings of the 4th international workshop on genetics of host-parasite interactions in forestry. Gen. Tech. Rep. PSW-GTR-240. Pacific Southwest Research Station, Forest Service, U.S. Department of Agriculture, Albany, CA, pp 326-335

Santini A, Ghelardini L, De Pace C, Desprez-Loustau ML, Capretti P, Chandelier A, Cech T, Chira D, Diamandis S, Gaitniekis T, Hantula J, Holdenrieder O, Jankovsky L, Jung T, Jurc D, Kirisits T, Kunca A, Lygis V, Malecka M, Marcais B, Schmitz S, Schumacher J, Solheim H, Solla A, Szabò I, Tsopelas P, Vannini A, Vettraino AM, Webber J, Woodward S, Stenlid J (2013) Biogeographical patterns and determinants of invasion by forest pathogens in Europe. New Phytol 197:238-250

Scheffer RJ (1983) Biological control of Dutch elm disease by Pseudomonas species. Ann Appl Biol 103:21-30

Scheffer RJ (1990) Mechanisms involved in biological control of Dutch elm disease. J Phytopathol 130:265-276

Scheffer RJ, Voeten JGWF, Guries RP (2008) Biological control of Dutch elm disease. Plant Dis 92:192-200

Sherif SM, Shukla MR, Murch SJ, Bernier L, Saxena PK (2016) Simultaneous induction of jasmonic acid and disease-responsive genes signifies tolerance of American elm to Dutch elm disease. Sci Rep-UK 6:21934

Sherif SM, Erland LA, Shukla MR, Saxena PK (2017) Bark and wood tissues of American elm exhibit distinct responses to Dutch elm disease. Sci Rep-UK 7:7114

Sherman-Broyles SL, Broyles SB, Hamrick JL (1992) Geographic distribution of allozyme variation in Ulmus crassifolia. Syst Bot 17:33-41

Sinclair WA, Welch DS, Parker KG, Tyler RJ (1974) Selection of American elms for resistance to Ceratocystis ulmi. Plant Dis Rep 58:784-788

Smalley EB, Guries RP, Lester RP (1993) American liberty elms and beyond: going from the impossible to the difficult. In: Sticklen MB, Sherald JL (eds) Dutch elm disease research: cellular and molecular approaches. Springer, New York, pp 26-45

Solla A (2000) Mejora genética de Ulmus minor Miller. Selección de ejemplares resistentes a la grafiosis. PhD thesis, Universidad Politécnica de Madrid

Solla A, Gil L (2002a) Xylem vessel diameter as a factor in resistance of Ulmus minor to Ophiostoma novoulmi. For Pathol 32:123-134

Solla A, Gil L (2002b) Influence of water stress on Dutch elm disease symptoms in Ulmus minor. Can J Bot 80:810-817

Solla A, Gil L (2003) Evaluating Verticillium dahliae for biological control of Ophiostoma novo-ulmi in Ulmus minor. Plant Pathol 52:579-585

Solla A, Bohnens J, Collin E, Diamandis S, Franke A, Gil L, Burón M, Santini A, Mittempergher L, Pinon J, Broeck AV (2005) Screening European elms for resistance to Ophiostoma novo-ulmi. For Sci 51:134-141 
Solla A, Dacasa MC, Nasmith C, Hubbes M, Gil L (2008) Analysis of Spanish populations of Ophiostoma ulmi and O. novo-ulmi using phenotypic characteristics and RAPD markers. Plant Pathol 57:33-44

Solla A, López-Almansa JC, Martín JA, Gil L (2015) Genetic variation and heritability estimates of Ulmus minor and Ulmus pumila hybrids for budburst, growth and tolerance to Ophiostoma novo-ulmi. iForest 8:422-430

Sutherland ML, Brasier CM (1995) Effect of d-factors on in vitro cerato-ulmi production by the Dutch Elm Disease pathogen Ophiostoma novo-ulmi. Mycol Res 99:1211-1217

Sutherland ML, Mittempergher L, Brasier CM (1995) Control of Dutch elm disease by induced host resistance. Eur J For Pathol 25:307-318

Sutherland ML, Pearson S, Brasier CM (1997) The influence of temperature and light on defoliation levels of elm by Dutch elm disease. Phytopathology 87:576-581

Temple B, Horgen PA, Bernier L, Hintz WE (1997) Cerato-ulmin, a hydrophobin secreted by the causal agents of Dutch elm disease, is a parasitic fitness factor. Fungal Genet Biol 22:39-53

Temple B, Pines PA, Hintz WE (2006) A nine year genetic survey of the causal agent of Dutch elm disease, Ophiostoma novo-ulmi, in Winnipeg, Canada. Mycol Res 110:594-600

Temple B, Bernier L, Hintz WE (2009) Characterization of the polygalacturonase gene of the Dutch elm disease pathogen Ophiostoma novo-ulmi. N Z J For Sci 39:29-37

Tovar A (1975) Columela y el vino de Jerez. In: Homenaje nacional a Lucio Junio Moderato Columela. Asociación de Publicistas y Escritores Agrarios Españoles, Cádiz pp 93-99

Townsend AM (1979) Influence of specific combining ability and sex of gametes on transmission of Ceratocystis ulmi resistance in Ulmus. Phytopathology 69:643-645

Townsend AM (2000) USDA genetic research on elms. In: Dunn CP (ed) The elms: breeding, conservation, and disease management. Kluwer Academic Publishers, Boston, pp 271-278

Townsend AM, Santamour FS (1993) Progress in the development of disease-resistant elms. In: Sticklen MB, Sherald JL (eds) Dutch elm disease research: cellular and molecular approaches. Springer, New York, pp 46-50

van Alfen NK, Turner NC (1975) Influence of a Ceratocystis ulmi toxin on water relations of elm (Ulmus americana). Plant Physiol 55:3112-3316

van Loon LC, Rep M, Pieterse CM (2006) Significance of inducible defense-related proteins in infected plants. Annu Rev Phytopathol 44:135-162

Venturas M, López R, Martín JA, Gascó A, Gil L (2014) Heritability of Ulmus minor resistance to Dutch elm disease and its relationship to vessel size, but not to xylem vulnerability to drought. Plant Pathol 63:500-509

Venturas M, Fuentes-Utrilla P, López R, Perea R, Fernández V, Gascó A, Guzmán P, Li M, RodríguezCalcerrada J, Miranda E, Domínguez J, González-Gordaliza G, Zafra E, Fajardo-Alcántara M, Martín JA, Ennos R, Nanos N, Lucena JJ, Iglesias S, Collada C, Gil L (2015) Ulmus laevis in the Iberian Peninsula: a review of its ecology and conservation. Forest 8:135-142

Ware GH (2000) The promise and future of urban elms. In: Dunn CP (ed) The elms: breeding, conservation, and disease management. Kluwer Academic Publishers, Boston, pp 331-339

Webber JF (1987) The influence of the $\mathrm{d} 2$ factor on survival and infection by the Dutch elm disease pathogen Ophiostoma ulmi. Plant Pathol 36:531-538

Webber JF (1993) D factors and their potential for controlling Dutch elm disease. In: Sticklen MB, Sherald JL (eds) Dutch elm disease research—cellular and molecular approaches. Springer, New York, pp $322-332$

Webber JF (2004) Experimental studies on factors influencing the transmission of Dutch elm disease. Invest Agrar: Sist Recur For 13:197-205

Webber JF, Hedger JN (1986) Comparison of interactions between Ceratocystis ulmi and elm bark saprobes in vitro and in vivo. T Brit Mycol Soc 86:93-101

Wegener R, Schulz S, Meiners T et al (2001) Analysis of volatiles induced by oviposition of elm leaf beetle Xanthogaleruca luteola on Ulmus minor. J Chem Ecol 27:499-515

Whiteley RE (2004) Quantitative and molecular genetic variation in Ulmus laevis Pall. PhD Thesis, Swedish University of Agricultural Sciences

Wiegrefe SJ, Sytsma KJ, Guries RP (1994) Phylogeny of elms (Ulmus, Ulmaceae): molecular evidence for a sectional classification. Syst Bot 19:590-612

Zalapa JE, Brunet J, Guries RP (2009) Patterns of hybridization and introgression between invasive Ulmus pumila (Ulmaceae) and native U. rubra. Am J Bot 96:1116-1128

Zalapa JE, Brunet J, Guries RP (2010) The extent of hybridization and its impact on the genetic diversity and population structure of an invasive tree, Ulmus pumila (Ulmaceae). Evol Appl 3:157-168 